\title{
A Conductor's Perspective on Stravinsky's "Danse sacrale" from "Le Sacre du printemps": Evaluation of Revisions, Analysis and Considerations for Conducting
}

Hanjin Sa

Follow this and additional works at: https://researchrepository.wvu.edu/etd

\section{Recommended Citation}

Sa, Hanjin, "A Conductor's Perspective on Stravinsky's "Danse sacrale" from "Le Sacre du printemps": Evaluation of Revisions, Analysis and Considerations for Conducting" (2017). Graduate Theses, Dissertations, and Problem Reports. 6549.

https://researchrepository.wvu.edu/etd/6549

This Dissertation is protected by copyright and/or related rights. It has been brought to you by the The Research Repository @ WVU with permission from the rights-holder(s). You are free to use this Dissertation in any way that is permitted by the copyright and related rights legislation that applies to your use. For other uses you must obtain permission from the rights-holder(s) directly, unless additional rights are indicated by a Creative Commons license in the record and/ or on the work itself. This Dissertation has been accepted for inclusion in WVU Graduate Theses, Dissertations, and Problem Reports collection by an authorized administrator of The Research Repository @ WVU.

For more information, please contact researchrepository@mail.wvu.edu. 
A Conductor's Perspective on Stravinsky's Danse sacrale from Le Sacre du printemps: Evaluation of Revisions, Analysis and Considerations for Conducting

\title{
HANJIN SA
}

\author{
Dissertation Submitted \\ to the College of Creative Arts \\ at West Virginia University \\ in partial fulfillment of the requirements for the degree of \\ Doctor of Musical Arts \\ in \\ Conducting
}

\author{
Mitchell Arnold, D.M., Committee Chair \\ Ernest Goeres, Ph.D. \\ John Hendricks, M.M. \\ Mikylah McTeer, D.M.A. \\ David Taddie, Ph.D.
}

School of Music

Morgantown, West Virginia

2017

Keywords: Conducting, Danse sacrale, Le sacre du printemps, Stravinsky, Boulez, Slonimsky

Copyright 2017 Hanjin Sa 


\begin{abstract}
A Conductor's Perspective on Stravinsky's Danse sacrale from Le Sacre du printemps:

Evaluation of Revisions, Analysis and Considerations for Conducting
\end{abstract}

Hanjin Sa

The final dance, Danse sacrale from the ballet Le Sacre du printemps by Igor Stravinsky (1882-1971) presents various challenges for conductors: both textual and technical. For the textual challenges, this research paper focuses on the comparative studies of various revisions, the early sketchbook, and the autograph full score. The study of correspondence between Stravinsky and the early conductors of Le Sacre (Pierre Monteux and Ernest Ansermet) also offers important clues for solving the puzzle with which Stravinsky himself had struggled for decades.

Both the 1943-revised version and Nicholas Slonimsky's re-barring of the Danse sacrale will be closely examined. Despite Stravinsky's wish that the 1943 version was to supersede the previous versions, it failed to become part of the final 1967 version; it was virtually ignored and not accepted as substitute performing material. Similarly, Slonimsky's re-barring was used by only two conductors: Serge Koussevitzky (for whom the re-barring was made) and Leonard Bernstein. This research paper will discuss the purposes and benefits, as well as problems of both Stravinsky's 1943 revision and Slonimsky's re-barring of the Danse sacrale.

In this research paper, an in-depth rhythmic analysis of the Danse sacrale will also be included. Following Pierre Boulez's rhythmic cell analysis, the author will go even further to find the hidden rhythmic structures that are symmetrical and transformational.

Finally, two important considerations for conducting the Danse sacrale will be discussed. First, determining the correct metrical groupings and the correct divisions for asymmetrical meters, according to the rhythmic structure, is key to finding an efficient way to conduct the rhythmically complex score of the Danse sacrale. Second, an important performance practice regarding the tempo issues in the Danse sacrale will be discussed with examples from various recordings, especially the three recordings that Stravinsky conducted in 1929,1940 , and 1960. 


\section{ACKNOWLEDGEMENT}

Upon the completion of my dissertation, I would like to express my sincere gratitude to the school of music of West Virginia University for their generous support throughout my studies in WVU. I would like to pay special tribute to Dr. Mitchell Arnold who advised and encouraged me from the very beginning of this project. His recommendations helped me to shape my research project in a more coherent way. It has been my great pleasure and privilege to work with him in the course of my DMA studies in WVU. Additionally, I am grateful to my committee members and especially Dr. David Taddie for his wisdom, time and effort in offering sound advice and feedback to refine my research paper.

West Virginia holds a very special place in my heart. I have met many wonderful friends who became like family to me. Special thanks to Nabil and Nina Jabbour, Dewey and Linda Rotruck, Homer and Peggy Ruckle and other members of First Baptist Church, Morgantown.

I would also like to acknowledge New York Philharmonic's Digital Archives for their willingness to share the digital copies of Leonard Bernstein's score of the Rite of Spring.

Finally, I am blessed with the invaluable support from my family and Jocelyn Lee. Their love and encouragement gave me strength to complete my Doctoral studies. 


\section{TABLE OF CONTENTS}

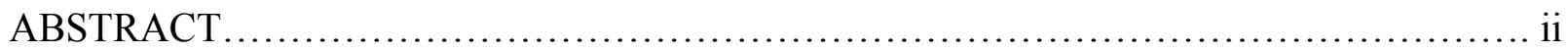

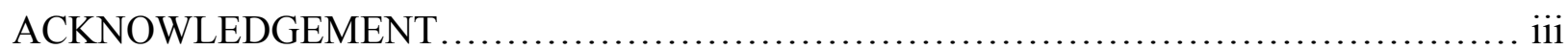

Chapter 1. Introduction/Review of Literature ..........................................

I. Introduction............................................................

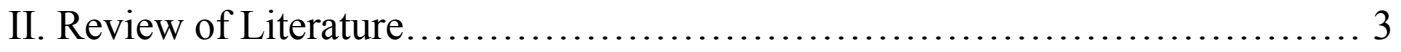

Chapter 2. Versions and Revisions of Le Sacre du printemps............................... 5

I. Sketches and Early Versions ............................................. 5

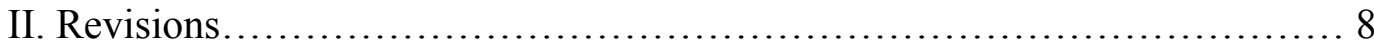

III. 1943 Revision of Danse sacrale............................................ 13

Chapter 3. Slonimsky's Re-barring of Danse sacrale .................................... 16

Chapter 4. Rhythmic Analysis of Danse sacrale ........................................... 23

I. Detailed Analysis of the A section and Coda II.......................... 26

II. Detailed Analysis of the $B$ section ........................................ 30

Chapter 5. A Conductor's Perspective .................................................. 34

Chapter 6. Summary and Conclusions................................................... 42

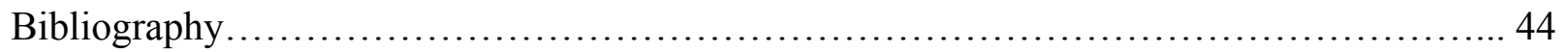


List of Tables

Table

Page

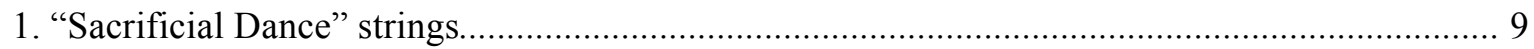

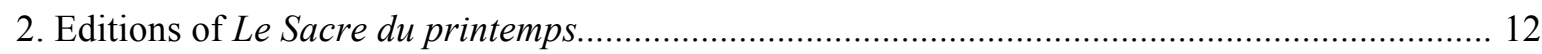

3. Labeling of the rhythmic structure in the Danse sacrale ............................................................ 25

4. Concordance of Tempo Indications in the Danse sacrale ....................................................... 39

5. Some Recorded Tempos in the Danse sacrale ......................................................................... 41

\section{List of Figures}

Figure $\quad$ Page

1. An early sketch of the music at no. 147 in the Danse sacrale .................................................. 5

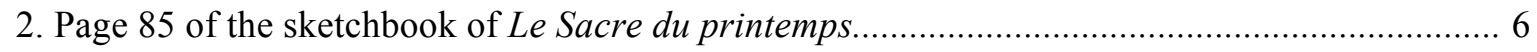

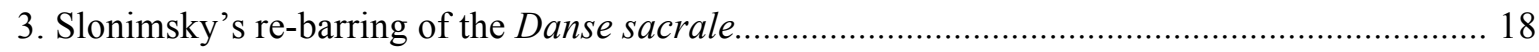

\section{List of Examples}

Example

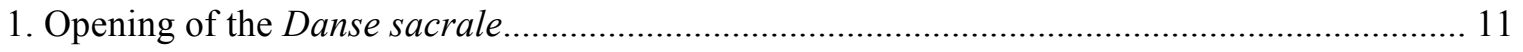

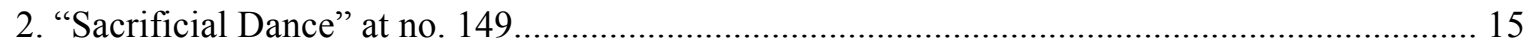

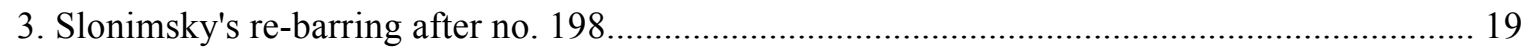

4. Bernstein's score of the Danse sacrale with Slonimsky's re-barring.................................... 20

5. 1943-Revised Version of the Danse sacrale ........................................................................... 21

6. Slonimsky's Re-barring at three measures before no. 145 and three measures after no. $145 \ldots .22$

7. Boulez's Rhythmic Schema for the A section of Danse sacrale ................................................ 26

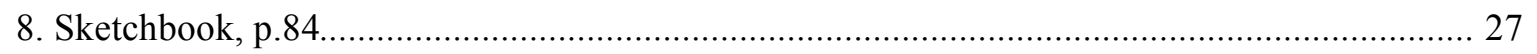

9. Boulez's Rhythmic Schema for the Section I of the Coda II of the Danse sacrale.................... 28

10. Boulez's Rhythmic Schema for the B section of Danse sacrale .............................................. 30

11. Boulez's Rhythmic Schema for the Period I of the B section of Danse sacrale...................... 31

12. New schema for the Period I of the B section of Danse sacrale ............................................ 31

13. Stravinsky corrects Monteux’s "wrong” divisions of five ..................................................... 35

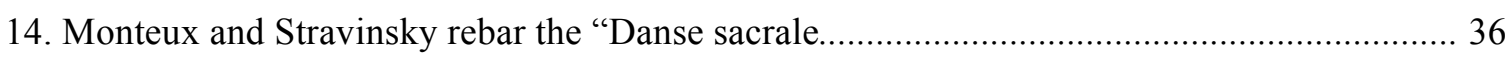

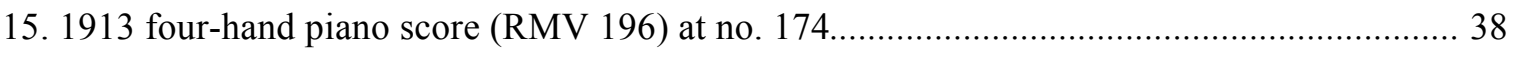




\section{Chapter I}

\section{Introduction/ Review of Literature}

\section{Introduction}

Stravinsky's Le Sacre du printemps is undoubtedly one of the most significant and influential pieces of the $20^{\text {th }}$ century. Since the famously scandalous 1913 Paris première, Le Sacre has slowly been accepted by the musical world. Although it was originally intended as ballet music for Diaghilev's Ballets Russes, Le Sacre earned more popularity in concert performances than when it was performed in ballet settings. ${ }^{1}$ In 1940 , the piece was one of eight classical pieces chosen for Disney's animated film, Fantasia. In Fantasia, the Russian piece of primitivism was newly translated into an animation portraying the prehistoric scenes with dinosaurs and volcanic eruptions.

Aside from its popular appeal, which Le Sacre continues to enjoy, it is arguably the most influential piece of the $20^{\text {th }}$ century. Stravinsky's revolutionary inventions of harmony, rhythm, and orchestration inspired many leading composers of the later generations such as Bartok, Messiaen and Boulez to name only a few. Such as polyrhythm, polymeter and polytonality that Stravinsky had already introduced in his previous ballet work, Petroushka he further developed his new musical languages in Le Sacre.

With his early Russian ballet triptych, especially Le Sacre as the most significant work, Stravinsky successfully created his own musical language. Joan Peyser points out the significance of Le Sacre, "All that began with Firebird and developed in Petroushka culminated in the Rite of Spring. Its spontaneity, bitonality, unconventional rhythms and irregular balance established the work as one of the artistic landmarks of its time." 2 Roman Vlad further supports Peyser's description, 'It is in every sense an 'extreme' work in which expressiveness is raised to a white-hot incandescence, the emancipation of dissonances is complete, and the dynamic violence of the music is without precedent."3

The Danse sacrale, in particular, portrays the extreme degrees of rhythmic complexity created by the use of constant metric changes and syncopations; a state of instability caused by relentless rhythmic drive. Stravinsky struggled more with the Danse sacrale than any other

\footnotetext{
${ }^{1}$ Stravinsky and Craft, Expositions and Developments (New York: Doubleday, 1962), 144.

2 Joan Peyser, The New Music (New York: Delacorte, 1971), 102.

${ }^{3}$ Roman Vlad, Stravinsky (London: Oxford University Press, 1967), 37.
} 
movements in Le Sacre. The reasons for his struggle might have been due to the fact that the complexity of the score of the Danse sacrale presents its own rhythmic ambiguities and orchestral balance problems.

Since the birth of Le Sacre, Stravinsky made several revisions (from the completion of the piece in 1912 to the last version in 1967) including the 1943-revised version of Danse sacrale. Associated Music Publishers separately published the newly revised version of the Danse sacrale. A thorough comparison study of the 1943 version of the Danse sacrale with other previous versions including the sketchbook and the 1913 autograph full score helps us to understand what Stravinsky originally intended, and how he found the solutions for many problems pertaining to the piece. Nevertheless, the 1943 version failed to become part of the final version in 1967.

Many conductors have struggled with the technical aspect of conducting Danse sacrale. Serge Koussevitzky's struggles with conducting Le Sacre had been observed by several musicians and critics including, for example, Nicholas Slonimsky ${ }^{4}$ and Nikolai Miakovsky. ${ }^{5}$ As a secretary and a rehearsal pianist for Koussevitzky in early 1920s, Slonimsky provided the renowned Russian conductor with a practical aid, the re-barring of the Danse sacrale. With his re-barring, Slonimsky re-grouped irregular metrical changes into the simple beat patterns of two, three and four. Although it provided a great help for Koussevitzky, the intrinsic rhythmic power had been sacrificed; the perpetual syncopations are turned into downbeats in Slonimsky's rebarring.

To understand the rhythmic structure and the inner spirit of the Danse sacrale, a proper analysis is required. Boulez's rhythmic cell analysis can help us to identify the rhythmic structures from the smallest units to the larger sections; after a rhythmic cell analysis the hidden symmetries and the play of rhythmic transformations can be revealed.

More than a century has passed since the creation of Le Sacre. As all masterpieces of arts renew themselves, Le Sacre is no exception. It is only possible, however, to unfold the many mysteries and ambiguities the score presents, through thorough investigations. Exploring the Danse sacrale can widen our perspectives on Le Sacre, arguably Stravinsky's most original and ingenious work.

\footnotetext{
4 Nicholas Slonimsky, Perfect Pitch (Oxford: Oxford University Press, 1988), 74.

5 Olga Manulkina, "Leonard Bernstein's 1959 Triumph in the Soviet Union," The Rite of Spring at 100 (Bloomington: Indiana University Press, 2017), 224.
} 


\section{Review of Literature}

As Stravinsky made a number of revisions to Le Sacre du printemps, it is essential for this research project to investigate the composer's intentions for each revision of the Danse sacrale. There are two very important early sources for Le Sacre: the sketchbook and the 1913 autograph full score. The sketchbook ${ }^{6}$ for Le Sacre was published in 1969 by Boosey and Hawkes. The Paul Sacher Foundation's Centenary edition of Le Sacre du printemps was published in 2013. It is comprised of a set of three volumes: a facsimile edition of the autograph fair copy of the work in full score, ${ }^{7}$ the autograph manuscript version for piano four hands, ${ }^{8}$ and a collection of essays by leading Stravinsky scholars. ${ }^{9}$ Russian Music Publisher published both the first edition in 1922 and the 1929 revision of Le Sacre. The 1943 revision of Danse sacrale was published by Associated Music Publishers. Boosey and Hawkes purchased the copyright of the piece from Russian Music Publisher in 1947, and published the subsequent revised versions until 1967. Other sources such as the correspondence between Stravinsky and his conductor colleagues such as Pierre Monteux and Ernest Ansermet, offer some important clues for corrections and revisions of the Danse sacrale.

Several writers and music scholars have studied the confusing and complicated history of the revisions for Le Sacre. Stravinsky's assistant, Robert Craft published three separate essays on Le Sacre's revisions. ${ }^{10}$ Louis Cyr's "Writing The Rite Right" 11 offers the most comprehensive rendition focusing on various source materials and revisions. Pieter van den Toorn's "Stravinsky and the Rite of Spring"12 also provides several important points of information concerning both the historical and theoretical contexts.

\footnotetext{
6 Igor Stravinsky, The Rite of Spring: Sketches 1911-1913 (London: Boosey \& Hawkes, 1969)

7 Ulrich Mosch, ed., Igor Stravinsky, Le Sacre du printemps: Facsimile of the Autograph Full Score (London: Boosey \& Hawkes, 2013)

${ }^{8}$ Felix Meyer, ed., Igor Stravinsky, Le Sacre du printemps: Manuscript of the Version for Piano Four Hands: Facsimile (London: Boosey \& Hawkes, 2013)

9 Herman Danuser, ed., Avatar of Modernity: The Rite of Spring Reconsidered (London: Boosey \& Hawkes, 2013)

10 Robert Craft, 1) "Le Sacre du printemps: The Revisions," Tempo 122 (1977), 2-8.

2) Vera Stravinsky and Robert Craft, Stravinsky in Pictures and Documents, Appendix B, « The Revisions, » (New York: Simon \& Schuster, 1978), 526-33.

3) ed., Stravinsky: Selected Correspondence, vol. 1, Appendix D, "Le Sacre du printemps: A Chronology of the Revisions," (New York: Alfred A. Knopf, Inc.), 398-406.

11 Louis Cyr, "Writing The Rite Right," Confronting Stravinsky (Berkeley: University of California Press, 1986)

12 Pieter C. van den Toorn, Stravinsky and The Rite of Spring (Berkeley: University of California Press, 1987)
} 
The author could find no study or survey done of Nicholas Slonimsky's re-barring of the Danse sacrale. However, the entire re-barring by Slonimsky can be accessed from the New York Philharmonic's Digital Archives. ${ }^{13}$

There have been a number of studies and analyses of Stravinsky's Le Sacre du printemps; the majority deal with pitch and harmonic structures (by major scholars including Allen Forte, Olivier Messiaen, and Pieter van den Toorn) while a relatively smaller number deal with the rhythmic structures. Both Olivier Messiaen and Pierre Boulez did rhythmic analyses of Le Sacre. In chapter 4, Boulez's rhythmic cell analysis for the Danse sacrale will be discussed in depth.

There are a few scholarly writings on Le Sacre that are pertinent to this research project. Most notably, Robert Fink's essay ${ }^{14}$ about the performance practice of Le Sacre includes many useful surveys and examples for the comparisons of tempo indications of the Danse sacrale in different versions, and the different tempos found on various recordings: most importantly Stravinsky's own three recordings (from 1929, 1940, and 1960) of Le Sacre. These examples will be examined in detail in chapter 5 .

13 Leonard Bernstein Score Collection, ID 2341. Courtesy of the New York Philharmonic Leon Levy Digital Archives.

${ }^{14}$ Robert Fink, "Rigoroso $(\delta=126)$ ": "The Rite of Spring" and the Forging of a Modernist Performing Style, Journal of the American Musicological Society, Vol. 52, No. 2 (Summer, 1999) 


\section{Chapter 2}

Versions and Revisions of Le Sacre du printemps

\section{Sketches and Early Versions}

An early sketch of the Danse sacrale can be found in Stravinsky's notebook that he used from 1912 to 1918. It contains two pages of sketches that will eventually become Part II's Introduction and the Danse sacrale. ${ }^{15}$ The notebook sketch (figure 1) resembles the second system on page 85 of the sketchbook of Le Sacre (as highlighted in figure 2). ${ }^{16}$ It also includes detailed instrumentations that were eventually incorporated in the 1913 autograph full score. A facsimile of the notebook sketch is shown in Figure 1.

Figure 1: An early sketch of the music at rehearsal no. 147 in the Danse sacrale dating from 1912 to 1918. Notice the pizzicato, arco indication in the first and third measure. They were deleted in the 1921 and 1929 revised editions. ${ }^{17}$

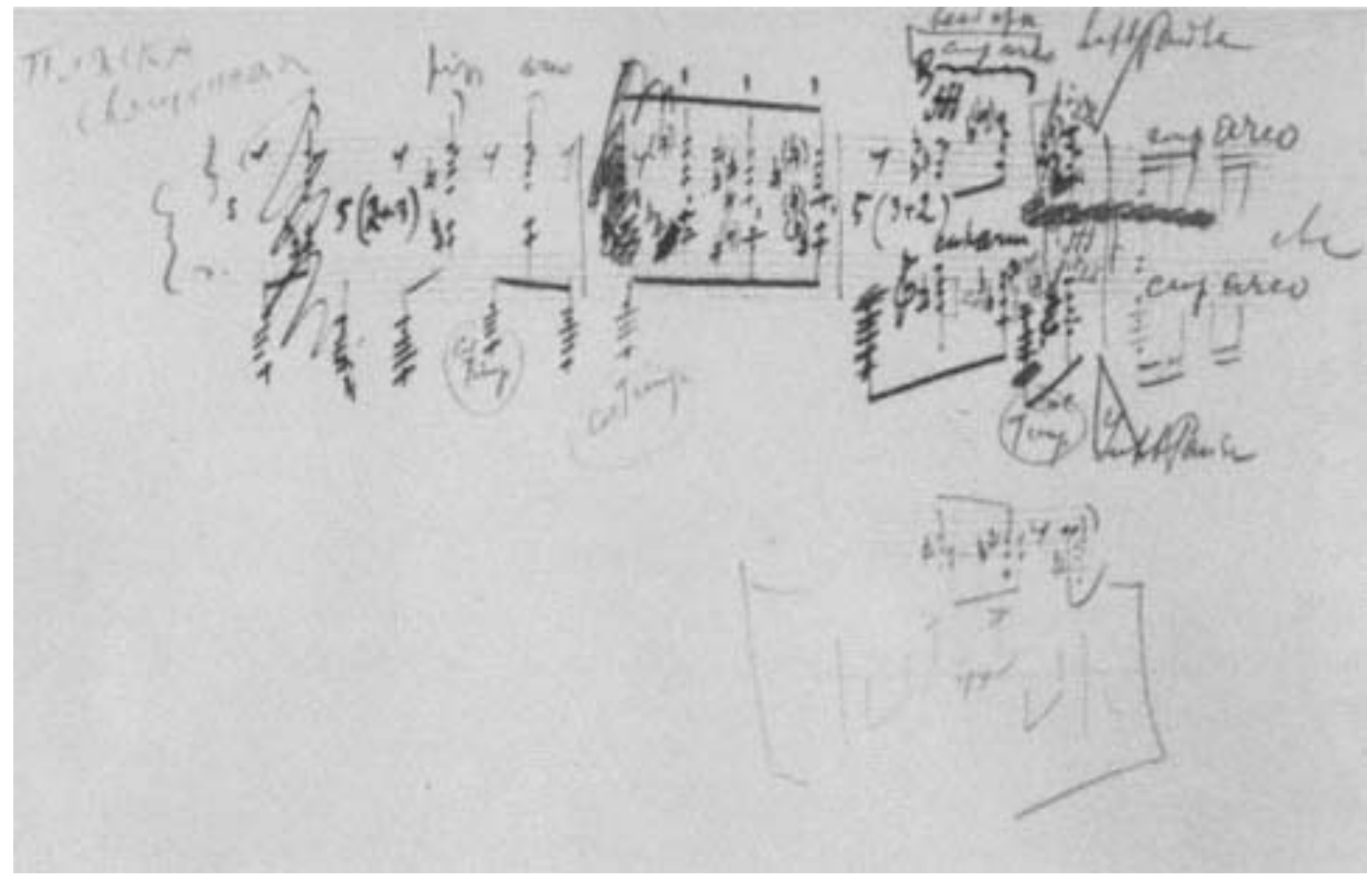

\footnotetext{
15 Pieter C. van den Toorn, Stravinsky and The Rite of Spring (Berkeley: University of California Press, 1987), 32.

16 Igor Stravinsky, The Rite of Spring: Sketches 1911-1913 (London: Boosey \& Hawkes, 1969)

17 Pieter C. van den Toorn, Stravinsky and The Rite of Spring (Berkeley: University of California Press, 1987), 33.
} 
Figure 2: The second system (the highlighted area) corresponds to the music at rehearsal no.147 in Figure 1. Notice the basic note value is eighth note (same as 1943 revision). However, Stravinsky changed the basic note value to the sixteenth note in the first edition in $1913 .{ }^{18}$

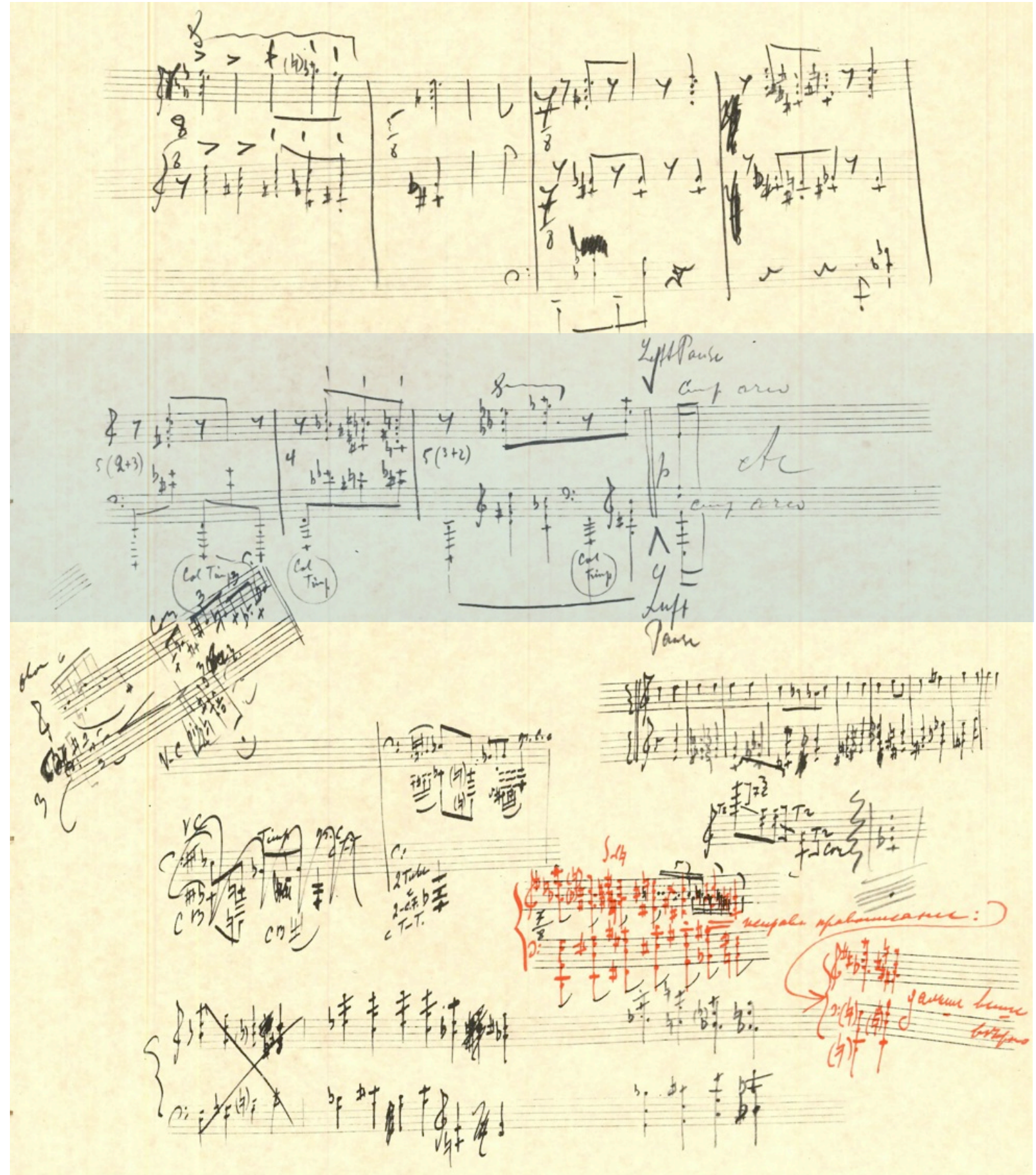

18 Igor Stravinsky, The Rite of Spring: Sketches 1911-1913 (London: Boosey \& Hawkes, 1969), 85. 
The sketchbook for Le Sacre dates from the summer of 1911 to November 17, 1912. Stravinsky was suffering from "a raging toothache" 19 while finishing the final pages of the Danse sacrale. The date for the completion was clearly indicated by his handwriting with blue and red pencils. The sketches for the Danse sacrale (pages 84-102 of the sketchbook) offer important insight into Stravinsky's creative process for writing, and later revising one of the most rhythmically complex scores. The layout for both "Glorification of the Chosen One" (pages 52, 59, 61 and 66 of the sketchbook) and "Sacrificial Dance," reveals that Stravinsky composed these two sections at the piano. "When rehearsing these passages during 1920s and 1930s, Stravinsky often recommended that bassists and timpanists visualize themselves as a pianist's left hand, the tutti orchestra as the same pianist's right hand. The tactic seems to have enhanced both the precision and the general rhythmic feel of this music." 20

The autograph of the full score was completed in Clarens ${ }^{21}$ on March 8, 1913. Subsequently, Stravinsky finished the newly added Introduction to Part II (before rehearsal no. 86 ) in the full score on March 29. Around the same time as Stravinsky continued working on the master copy of the full score, Pierre Monteux ${ }^{22}$ conducted his first orchestral rehearsal of the piece in Paris with the first-draft score of Part I. ${ }^{23}$ After the first orchestral rehearsals, Monteux wrote to Stravinsky reporting four problematic passages regarding issues of instrumentation and balance. ${ }^{24}$ Stravinsky revised all the passages mentioned by Monteux. The autograph manuscript version for piano, four hands, is dated April 15, 1913; it was later published by Édition Russes de Musique $^{25}$ on May 21, 1913. Stravinsky and Claude Debussy used the piano four hands version when they performed together privately at the home of Louis Laloy ${ }^{26}$ in late May 1913. On May 1, the copyist's manuscript of the full score was completed. It eventually served Monteux as a conductor's score at the world première in Paris, on May 29, 1913.

\footnotetext{
19 Stravinsky and Craft, Expositions and Developments (New York: Doubleday, 1962), 142.

20 Robert Craft, “Commentary to the Sketches," The Rite of Spring: Sketches 1911-1913 (London: Boosey \& Hawkes, 1969$), 17$.

21 A Swiss city where Stravinsky wrote his ballets Le Sacre du printemps (1913) and Pulcinella (1920).

22 A French conductor (1875-1964) who premièred Le Sacre as well as other important ballet works for Sergei Diaghilev's Ballets Russes company between 1911 and 1914. He was later Music Director of the Boston Symphony and founded the Pierre Monteux School of Conducting in Maine which continues today.

23 Pieter C. van den Toorn, Stravinsky and The Rite of Spring (Berkeley: University of California Press, 1987), 37.

24 Robert Craft, ed., Stravinsky: Selected Correspondence, vol. 2, 52-54.

${ }^{25}$ Russian Music Publisher (Russischer Musik Verlag; RMV): founded in 1909 by Serge Koussevitzky and his first wife, Natalie.

${ }^{26}$ A French musicologist, writer and sinologist (1874-1944) who was the first biographer of Claude Debussy.
} 


\section{Revisions}

Since the première of Le Sacre, Stravinsky made numerous revisions over the course of time spanning more than a half-century. Later, Stravinsky confessed, "I would go on eternally revising my music... were I not too busy composing more of it, and I am still far from content with everything in Le Sacre."27 The errors and musical problems were first discovered by contemporary conductors with whom Stravinsky closely associated for performing his works: most notably Pierre Monteux and Ernest Ansermet. ${ }^{28}$ Their observations from the rehearsals and suggestions for the possible solutions played important roles in the process of revisions. Stravinsky also discovered a number of errors when he studied, rehearsed or performed the piece. Revisions for the Danse sacrale generally involve changes in scoring and barring.

The first edition of Le Sacre was published in 1921, but was released a year later. After the failed attempt to engrave the score due to the interruption by World War I in 1914, Stravinsky made numerous changes in the process of preparation for the revival of the ballet (with Ansermet conducting) on December 15, 1920. The first published full score (RMV 197, 1921) and the pocket score (RMV 197b, 1922) are the revised editions from the 1913 autograph full score.

In the summer of 1922 prior to the Berlin première of Le Sacre (two performances on November 19 and 20, 1922 both conducted by Ansermet), the Swiss conductor studied the new edition of the score and compiled a list of errors (Erratumblatt) with a set of five "directions for the conductor." 29 In his Erratumblatt, which he sent to Stravinsky on August 9, 1922, Ansermet included suggestions for deleting the pizzicato markings in the Danse sacrale from rehearsal no. 186 to the end of the piece. Stravinsky promptly replied on August 11 that he approved Ansermet's suggestions:

I have verified, added to, and corrected everything in the "Errata."... The directions for the conductor must be printed separately, for which reason I ask you to make a special sheet for them.... The page with the "Roster of the instruments in Le Sacre" must precede these "Errata," "Direction," etc. ${ }^{30}$

In the following letter (written on August 14, 1922), Ansermet explained that the rationale for the removal of all pizzicati from the Danse sacrale had been for practical reasons:

\footnotetext{
27 Stravinsky and Craft, Expositions and Developments (New York: Doubleday, 1962), 147.

28 A Swiss conductor (1883-1969) who was the conductor for Diaghilev's Ballets Russes from 1915 to 1923.

29 Pieter C. van den Toorn, Stravinsky and The Rite of Spring (Berkeley: University of California Press, 1987), $42,44$.

30 Robert Craft, ed., Stravinsky: Selected Correspondence, vol. 1 (New York: Alfred A. Knopf, Inc.), 159.
} 
The corrections in the old proof score, which served as the basis for the present engraved score... were made during rehearsals and thus without the care one usually applies to correcting proofs. Thus, for the "Sacrificial Dance," it was decided to delete the pizzicati, and they were in fact eliminated... They were deleted as a matter of principle: we were being rushed, there were few string players available, and even these were below average; we had enough trouble in coping with the rhythmic complexities alone. ${ }^{31}$

However, in the later part of the same letter, Ansermet questions whether the complete removal of pizzicati is the best solution. He suggested that alternating pizz. and arco might be the better solution for bringing out the clarity and definite contours in sound:

But now I am seriously wondering if we do right in sticking to that decision. After all, some day we'll be blessed with better performers and performing conditions. In that case, wouldn't writing the strings [alternately] unison pizz. and divisi arco be better the solution? And won't the dryness of pizz. strings accompanying the oboes provide a more concise and clear-cut rhythm than any bowing ever could?... intervening pizz. would provide clarity and definite contours to the music. ${ }^{32}$

We do not know how much Ansermet's suggestion contributed to Stravinsky's later revisions. Nevertheless, Stravinsky seemed to have changed his mind for each revision of the Danse sacrale: 1922 (all pizz. deleted), 1929 (reinstated pizz. at no. 186-188, 189, ${ }^{33}$ and alternating pizz.-arco from no. 192-end), and since 1948 (all pizz. deleted). Louis Cyr provides a convenient table that shows all these changes in different versions for the Danse sacrale: including the 1943 revision with its new rehearsal numbers (see Table 1 below).

Table 1. "Sacrificial Dance" (strings) ${ }^{34}$

\begin{tabular}{|c|c|c|c|c|c|c|}
\hline $\begin{array}{l}\text { Rehearsal } \\
\text { numbers }\end{array}$ & $\begin{array}{c}1913 \\
\text { (Ms. + ERM proofs) }\end{array}$ & $\begin{array}{c}1922 \\
(\text { ERM) }\end{array}$ & $\begin{array}{c}1930 \\
\text { (ERM) }\end{array}$ & $\begin{array}{r}\text { Since } 1948 \\
(\text { B. }+ \text { H. })\end{array}$ & $\begin{array}{r}1943 \\
\text { A.M.P. }\end{array}$ & $\begin{array}{l}\text { Rehearsal } \\
\text { numbers }\end{array}$ \\
\hline $186-188$ & $\begin{array}{l}\text { pizz. for } \\
\text { all strings }\end{array}$ & $\begin{array}{l}\text { pizz. } \\
\text { deleted }\end{array}$ & $\begin{array}{l}\text { pizz. } \\
\text { reinstated } \\
\text { (exc. Bassi) }\end{array}$ & $\begin{array}{l}\text { pizz. } \\
\text { deleted }\end{array}$ & $\begin{array}{l}\text { pizz. to } \\
\text { each "C" } \\
\text { of Celli }\end{array}$ & $45-48$ \\
\hline 189 & $\begin{array}{l}\text { pizz. for } \\
\text { all strings }\end{array}$ & $\begin{array}{l}\text { pizz. } \\
\text { deleted }\end{array}$ & $\begin{array}{l}\text { pizz. } \\
\text { reinstated } \\
\text { (exc. Bassi) }\end{array}$ & $\begin{array}{l}\text { pizz. } \\
\text { deleted }\end{array}$ & $\begin{array}{l}\text { pizz. for } \\
\text { all strings }\end{array}$ & 49 \\
\hline $190-191$ & $\begin{array}{l}\text { upper strings: } \\
\text { alternating } \\
\text { pizz.-arco } \\
\text { Bassi: pizz. } \\
\text { continuous }\end{array}$ & $\begin{array}{l}\text { pizz. } \\
\text { deleted }\end{array}$ & $\begin{array}{l}\text { pizz. } \\
\text { deleted }\end{array}$ & $\begin{array}{l}\text { pizz. } \\
\text { deleted }\end{array}$ & $\begin{array}{l}\text { pizz. remain } \\
\text { deleted }\end{array}$ & $50-53+2$ \\
\hline 192-end & $\begin{array}{l}\text { alternating } \\
\text { pizz.-arco } \\
\text { for all strings }\end{array}$ & $\begin{array}{l}\text { parts: } \\
\text { pizz. } \\
\text { deleted } \\
\text { score: } \\
\text { as } 1913\end{array}$ & $\begin{array}{l}\text { alternating } \\
\text { pizz.-arco } \\
\text { (exc. Bassi) }\end{array}$ & $\begin{array}{l}\text { pizz. } \\
\text { deleted }\end{array}$ & $\begin{array}{l}\text { pizz. } \\
\text { reinstated } \\
\text { for all } \\
\text { strings } \\
\text { (as in 1913) }\end{array}$ & $53+3$-end \\
\hline
\end{tabular}

${ }^{31}$ Previously published as “Une letter inedited d'Ansermet à Stravinsky à propos du 'Sacre du printemps, ," Revue musicale de Suisse romande (1980): 210-15. (Translated in English by Louis Cyr) 32 Ibid.

${ }^{33}$ From this point on, all the numbers indicate rehearsal numbers.

34 Louis Cyr, "Writing The Rite Right," Confronting Stravinsky (Berkeley: University of California Press, 1986), 170. 
Stravinsky was to conduct Le Sacre with the New York Philharmonic in concert performance on January 22, 1925. But he withdrew from the engagement due to the lack of rehearsal time. However, there were rumors circulating that Stravinsky's conducting technique had not been competent enough for the challenges of Le Sacre. ${ }^{35}$ In the end, Wilhelm Furtwängler ${ }^{36}$ had stepped in to conduct the performance. The following year, Stravinsky conducted Le Sacre for the first time on February 28, 1926, with the Concertgebouw Orchestra in Amsterdam. While studying the score in January, he made a number of changes to the score: rewriting the entire "Evocation of the Ancestors" and portions of the "Sacrificial Dance,"37 moving the fermata in the opening measure of the Danse sacrale from the first to the last sixteenth rest, etc. Although both the re-orchestration and the changes in harmony in numerous places are notable, the most conspicuous change is the re-barring of the "Evocation" and the “Sacrificial Dance." As a result, twenty pages were newly engraved for the 1929-revised version. Previous asymmetrical meters $(9 / 8,5 / 16,7 / 16$, etc.) from these movements, now became simple meters of duple or triplet units. $(3 / 8,2 / 16.3 / 16$, etc.) Stravinsky explains the rationale for the adaptation of the new grouping with the smaller units in the letter to Ansermet on January 30, 1926:

What interests me above all is the end of the Danse sacrale, since at the beginning-and when the same music occurs a half-step lower, a little farther along (no. 167)-I have succeeded in grouping the measures while redoing the instrumentation... in a way that more clearly defines the bass and the dialectical structure of the phrasing, and at the same time determines the accentuation. ${ }^{38}$

He later confirmed his point in Expositions and Developments (1962) that "The smaller measures proved more manageable for both conductor and orchestra, and they greatly simplified the scansion of the music." 39

In a letter of April 18, 1929, Ansermet agreed with Stravinsky's point that the smaller measure divisions proved to have more benefits in the December 1928 Paris concert:

Let me draw your attention especially to the change of the 3/8, 9 measures before the end of no. 142, and to the $3 / 16$ measures (rather than the groupings of 6/16s) from no. 192; the 3/16s are easier and they produce greater exactitude in performance. ${ }^{40}$

\footnotetext{
35 Robert Craft, “Le Sacre du printemps: The Revisions,” Tempo 122 (1977), 4.

36 A renowned German conductor (1886-1954) who led the Berlin Philharmonic (1922-1945, 1952-1954)

37 Pieter C. van den Toorn, Stravinsky and The Rite of Spring (Berkeley: University of California Press, 1987), 44.

38 Robert Craft, ed., Stravinsky: Selected Correspondence, vol. 1 (New York: Alfred A. Knopf, Inc., 1982), 185.

39 Stravinsky and Craft, Expositions and Developments (New York: Doubleday, 1962), 147.

${ }^{40}$ Claude Tappolet, ed., Correspondence: Ernest Ansermet-Igor Stravinsky, vol.2 (Geneva: George Éditeur, 1991$), 182$.
} 
Example 1 compares several different versions (from the sketchbook to the 1943revised version) of the opening of the Danse sacrale. Several observations are noteworthy. (1) From 1929 version onwards, the placement of the fermata in the first measure moved from the first beat to the third beat. (2) The basic rhythmic value was changed from eighth note to sixteenth note in the 1913 autograph and the 1929 revision, which was changed back to eighth note in the 1943 revision. (3) The subdivision of $3+2$ in the second measure was implied by the bass note beam both in the sketchbook and the 1913 autograph. (4) From 1929 version onwards, the second measure (5/8 from the sketchbook, and 5/16 from the 1913 autograph) was split into two measures. (5) The grouping of the two split measures (the second and the third measure) changed from $(2+3)$ in the 1929 revision to $(3+2)$ in the 1943 revision.

EXAMPLE 1: Opening of the Danse sacrale ${ }^{41}$
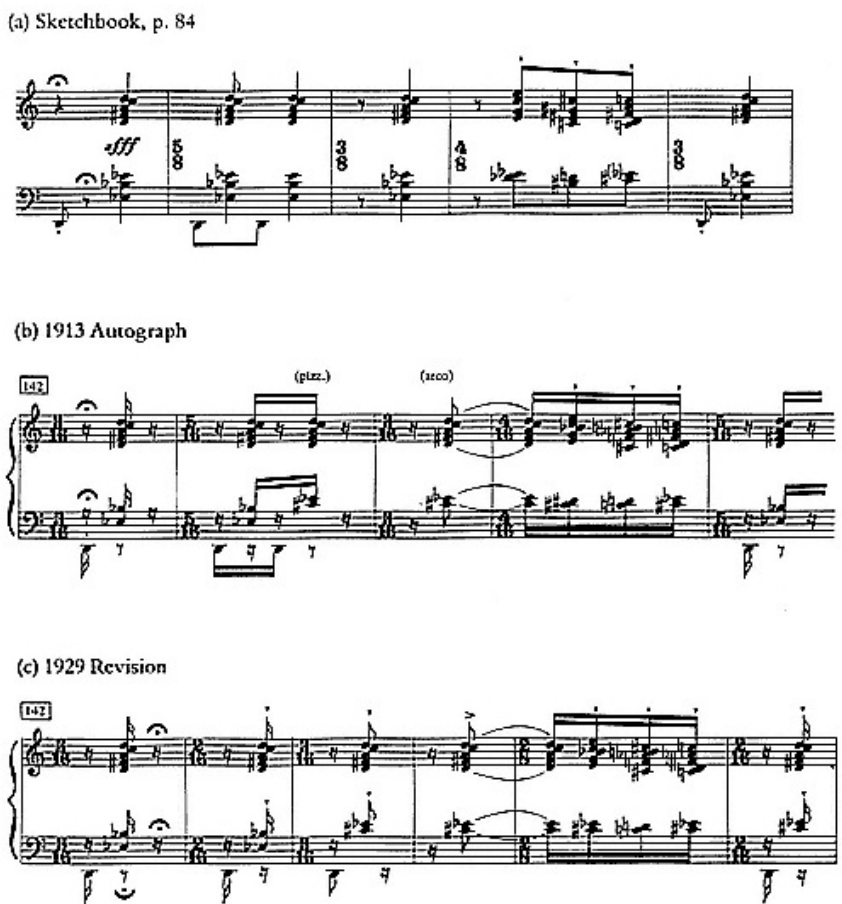

(d) 1943 Revision

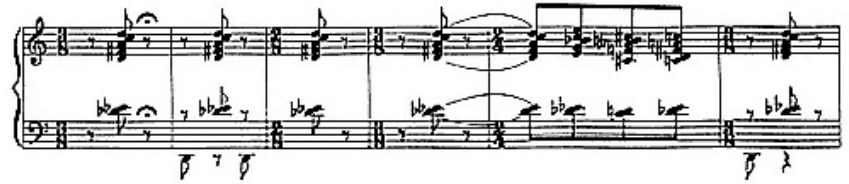

\footnotetext{
41 Pieter C. van den Toorn, Stravinsky and The Rite of Spring (Berkeley: University of California Press, 1987), 55.
} 
The 1929 revised version was widely accepted by leading conductors for more than three decades (before the publication of the newly engraved Boosey and Hawkes score of 1967). The subsequent versions $(1948,1965$, and 1967) are essentially the corrected reprints of the 1929 edition. $^{42}$ Two things need to be noted. First, both 1922 and 1929 editions share the same catalogue number (RMV 197, 197b). Second, the copyright of Le Sacre was transferred from Russian Music Publisher to Boosey \& Hawkes in 1947; RMV 197 became B\&H 16333. Pieter van den Toorn provides a comprehensive table of all editions of $L e$ Sacre with remarks (see Table 2 below).

Table 2. Editions of Le Sacre du printemps ${ }^{43}$

\begin{tabular}{|c|c|c|}
\hline YEAR & EDITION & REMARKS \\
\hline 1913 & RMV 196 & $\begin{array}{l}\text { Four-hand piano arrangement by Stravinsky. Barring of "Evocation" } \\
\text { and "Sacrificial Dance" conforms to } 1913 \text { autograph, full score. }\end{array}$ \\
\hline 1921 & $\begin{array}{c}\text { RMV } 197 \\
\text { RMV } 197 b \\
\text { (large and pocket scores) }\end{array}$ & $\begin{array}{c}\text { First edition, released } 1922 \text {. Barring of "Evocation" reverts to } \\
\text { sketchbook version (pp. 73-74). }\end{array}$ \\
\hline 1929 & $\begin{array}{l}\text { RMV } 197 \\
\text { RMV } 197 b\end{array}$ & $\begin{array}{l}\text { Second, revised edition. "Edited by F. H. Schneider" (p. 3, pocket } \\
\text { score). } 20 \text { pages newly engraved to cover } 1926 \text { reorchestration and } \\
\text { re-barring of "Evocation" and "Sacrificial Dance." }\end{array}$ \\
\hline 1945 & $\begin{array}{l}\text { Associated Music } \\
\text { Publishers }\end{array}$ & $\begin{array}{l}\text { Revised version of "Sacrificial Dance" completed in } 1943 . \text { Major } \\
\text { changes in orchestration, barring, and pitch. Unit of beat changed } \\
\text { from } 16 \text { th to } 8 \text { th. }\end{array}$ \\
\hline 1948 & $\begin{array}{l}\text { B\&H } 16333 \text { (large and } \\
\text { pocket scores) }\end{array}$ & $\begin{array}{c}\text { Corrected reprint of } 1929 \text { revised edition, RMV 197. Copyright } \\
\text { assigned to B\&H } 1947 .\end{array}$ \\
\hline 1952 & B\&H 17271 & Reprint of RMV 196 without modifications. \\
\hline 1965 & B\&H 16333 & $\begin{array}{l}\text { Corrected reprint of } 1948 \text { edition. "Revised } 1947 \text { version"; "Reprinted } \\
\text { with corrections 1965" (p. 1, large score); "Revised 1947" (p. 3, } \\
\text { pocket score). }\end{array}$ \\
\hline 1967 & B\&H 19441 & $\begin{array}{l}\text { Newly engraved edition. "Revised 1947. New edition 1967" (p. 1, } \\
\text { large score); "Re-engraved edition 1967" (title page, pocket score). }\end{array}$ \\
\hline 1968 & B\&H 17271 & $\begin{array}{l}\text { Corrected reprint of } 1952 \text { edition. } 11 \text { pages newly engraved, } \\
\text { primarily for "Evocation" and "Sacrificial Dance." }\end{array}$ \\
\hline
\end{tabular}

\footnotetext{
42 Pieter C. van den Toorn, Stravinsky and The Rite of Spring (Berkeley: University of California Press, 1987), 40. 43 Ibid., 41.
} 


\section{1943 Revision of Danse sacrale}

In 1943, Stravinsky completely revised the Danse sacrale and Associated Music Publishers published it on December 1943. On November 6, 1948, Stravinsky wrote a letter to Ralph Hawkes, explaining that the new version for the Danse sacrale should supersede the previous versions:

The 1943 Associated Music Publishers' version of the Danse sacrale, though requiring the same large orchestra, is much easier to read and to play, as well as definitely superior in balance and sonority. ${ }^{44}$

Another motive for revising the Danse sacrale can be found in a letter published in the New York Times, December 28, 1950:

I have considered revising the Danse sacrale for many years. My long experience in conducting it ... convinced me that ... changes in orchestration would clarify the harmonies and the design, that much in the original version was simply not heard, and that changes in the re-barring would simplify performance. I also changed the unit of beat from the sixteenth to the eighth and divided the five-beat bars into twos and threes ... I wanted to prepare this new version for my recording with the New York Philharmonic in a project for The Rite of Spring, and I had already finished the revised Danse sacrale when this project fell through ... The real problems posed in revision are to determine when a change in spelling becomes a change in structure and to show how these changes affect the form of the original. ${ }^{45}$

As Stravinsky described above, the 1943 revision of the Danse sacrale shows two significant changes: the eighth note as the basic note value and the re-barring. The metrical order of the second (3/8) and the third (2/8) measures in the opening follows the subdivision $(3+2)$ from the sketchbook and the original 1913 version. In the 1929 version, it reversed the order to $2 / 16$ followed by $3 / 16$. Stravinsky also changed the harmony and the orchestration. For example, he eliminated $\mathrm{B}$ flat from the earlier versions and added $\mathrm{D}$ flat ${ }^{46}$ in the very first chord. Other than the obvious changes of the instrumentation, the author will discuss more subtle but significant observations for the 1943 revision. (1) Adding 'pizz.' for Cello and Bass parts: the third beat of the second measure in the very beginning reinforcing the timpani upbeat. In the 1929 version (RMV 197), it is the downbeat of the third measure, which is played by the second timpani. At one measure before rehearsal no. 2 in the new version, ${ }^{47}$ he added div. pizz. in the cello part to double the trombones. At no. $45-48$, he added pizz. on each note $C$ of Celli. ${ }^{48}$

\footnotetext{
44 Robert Craft, ed., Stravinsky: Selected Correspondence, vol. 3 (New York: Alfred A. Knopf, Inc., 1982), 324.

45 Robert Craft, “Le Sacre du printemps: The Revisions,” Tempo 122 (1977), 8.

${ }^{46}$ See 'Example 1' in page 9.

47 Since the 1943 revision is made only for the Danse sacrale, Stravinsky did not conform the rehearsal numbers to other previous versions. In the 1943 version, rehearsal numbers start from 1.

${ }^{48}$ See 'Table 1' in page 7.
} 
(2) Deletion of the timpani part (no. 147 in RMV 197) at no. 6: tuba doubles the bass part. With the elimination of note $F$ on the third beat at no. 6 , the symmetrical inversion in timpani and bass is now lost.

(3) Reinstatement of the timpani octaves in note $F$ in the third measure of no. 5: Stravinsky returns to the original 1913 version where he initially wrote $F$ octaves at no. 146.

(4) Deletion of note $D$ in tuba and bass parts on the third beat of two measures before no. 5: Stravinsky again returns to the original 1913 version where he omitted the note $D$ at two measures before no. 146. This note was added in the 1929 version to parallel to the previous occurrence on the downbeat of two measures before no. 145.

(5) Unifying the basic note value as an eighth note consistently throughout. Previously, Stravinsky used both sixteenth and eighth notes in the 1929 version where he wrote eighths instead of sixteenths in the third and the fourth measures in the opening of Danse sacrale. It is consistently written this way when the eighth notes come on the second beat of $3 / 16$ measures. In the 1943 revision, all basic note values are eighth notes consistently throughout the piece.

Another striking difference between the 1943 version and the previous versions can be found at no. 8-26 (no. 149-167 in the 1913 original version and RMV 197). In the 1943 version, Stravinsky removes all the beams over the bar lines giving each chord separate punctuation. ${ }^{49}$ Stravinsky later explained, "My main purpose in revising the Danse sacrale was to facilitate performance by means of an easier-to-read unit of beat."

Despite the benefits that 1943 revision provide, it also presents problems and disadvantages. By removing the beams over the bar lines, the sense of the longer groupings (later, Boulez uses the concept of a 'rhythmic cell' in his analysis of the Danse sacrale) was lost. Additionally, the texture of the orchestration became so thin that the relentless and forceful nature of the piece was diminished considerably. Some of the re-barring caused a weakening of the rhythmic impulses: for example, the strong attack on the third beat in the second measure of the very beginning loses the power that the downbeat gives from the previous version (RMV 197). All these factors might have contributed to the fact that the 1943 revision of the Danse sacrale failed to be incorporated in later versions of Le Sacre.

\footnotetext{
49 See 'Example 2' on page 13.

${ }^{50}$ Stravinsky and Craft, Expositions and Developments (New York: Doubleday, 1962), 147.
} 
EXAMPLE 2: "Sacrificial Dance"51 at rehearsal no. 149

(a) Sketchbook. pp. 90-91
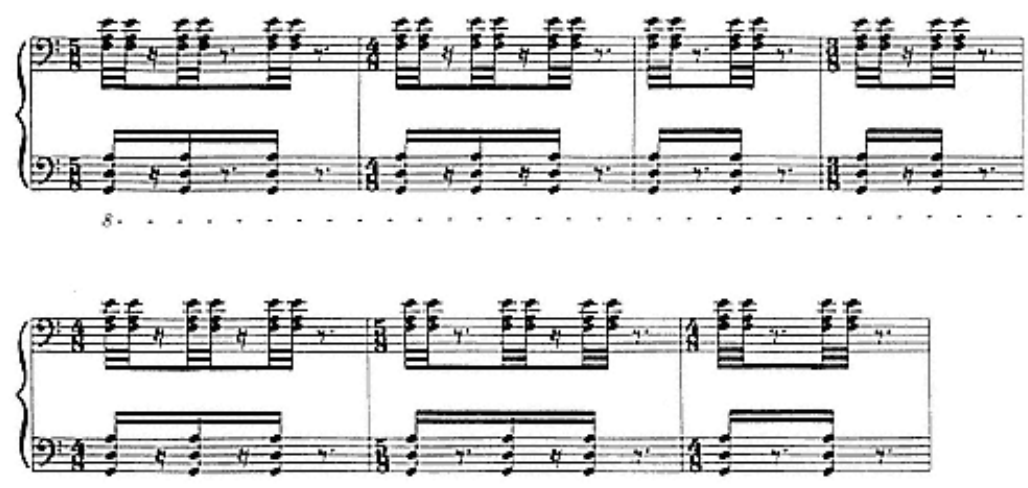

(b) 1913 Autograph
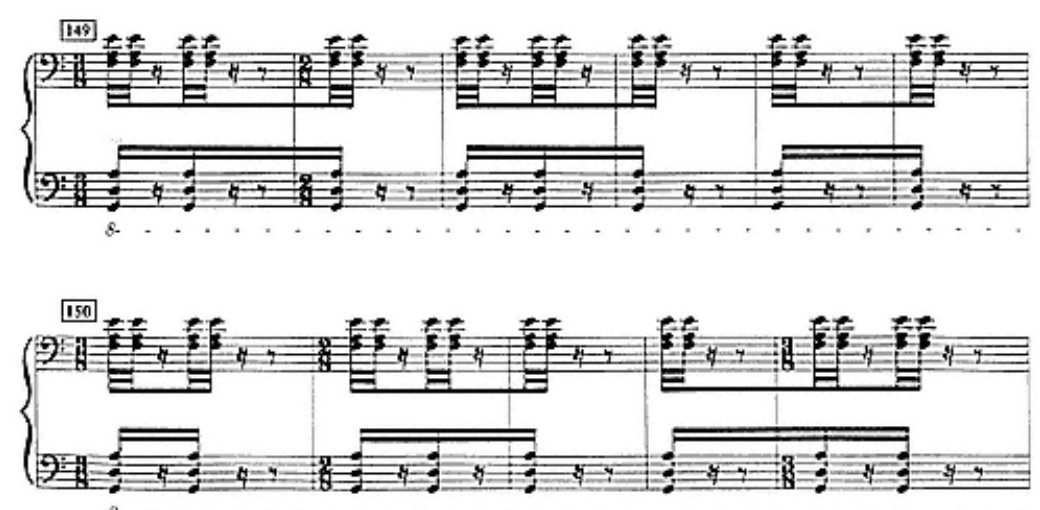

(c) 1943 Revision
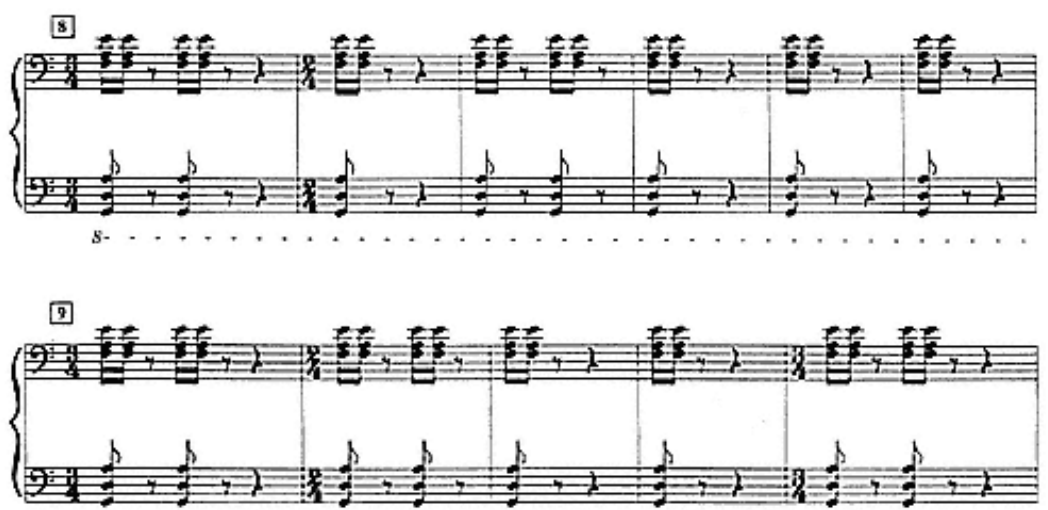

\footnotetext{
51 Pieter C. van den Toorn, Stravinsky and The Rite of Spring (Berkeley: University of California Press, 1987), 52-53.
} 


\section{Chapter 3}

\section{Slonimsky's Re-barring of Danse sacrale}

Nicholas Slonimsky (1894-1995) was a Russian born-American conductor, composer, author and musicologist. He was an editor of Baker's Biographical Dictionary of Musicians from 1958 to 1992. Among his numerous writings about music and musical reference, the most notable works include Thesaurus of Scales and Melodic Patterns and Lexicon of Musical Invective. In the early 1920s, Slonimsky was a rehearsal accompanist and a secretary to Serge Koussevitzky. ${ }^{52}$

As an avid advocate of new music, Koussevitzky promoted new Russian composers by purchasing and publishing the catalogues of their works through his own publisher, Russischer Musik Verlag, by whom the score of Le Sacre was first published in 1921. The major Russian composers include Sergei Rachmaninoff, Sergei Prokofiev, Alexander Scriabin, Nikolai Medtner and Igor Stravinsky.

Koussevitzky conducted the premières of a number of important works by Russian composers. Of Stravinsky's major ballet scores, he conducted the Russian premières of Petrushka (January 1913 in St. Petersburg) and Le Sacre (February 1914 in Moscow and St. Petersburg). One impression of Koussevitzky's early performance of Le Sacre was by Nikolai Miakovsky ${ }^{53}$ who wrote, "Often it was a mess... Koussevitzky did not have command of Le Sacre." 54

Even seven years after the first experience of conducting Le Sacre, Koussevitzky's conducting technique did not seem to improve. In his autobiography, Slonimsky shares a similarly negative impression of Koussevitzky's inadequate conducting technique when he recalled the experience of working with Koussevitzky in 1921:

To my dismay, I realized that Koussevitzky was incapable of coping with these [metrical] complications of the score... It occurred to me that the situation could be remedied by combining adjacent bars so as to reduce the basic beat to an eighth-notes; for instance, the succession of bars of $3 / 16,2 / 8.1 / 16,4 / 8$ could be integrated into a single bar of $4 / 4 .^{55}$

\footnotetext{
52 A Russian-born conductor (1874-1951) who served as music director of the Boston Symphony Orchestra from 1924 to 1949.

${ }^{53}$ A Russian and Soviet composer (1881-1950) who wrote 27 symphonies and taught at the Moscow Conservatory (1921-1950).

54 Olga Manulkina, "Leonard Bernstein's 1959 Triumph in the Soviet Union," The Rite of Spring at 100 (Bloomington: Indiana University Press, 2017), 224.

55 Nicholas Slonimsky, Perfect Pitch (Oxford: Oxford University Press, 1988), 74.
} 
As a result, Slonimsky made a special version of the Danse sacrale from Le Sacre with his re-barring. It was initially intended to aid Koussevitzky for his preparation for the Paris performance of Le Sacre in 1921. Slonimsky re-barred by drawing vertical lines with blue pencil on Koussevitzky's score (the first edition of Le Sacre 1921: RMV 197). Subsequently, his rebarring was transferred to the orchestra parts of Le Sacre that were used in Paris (1921) and in Boston. Since then, Koussevitzky used it in all his future performances of the work. ${ }^{56}$ Later, Koussevitzky's protégé, Leonard Bernstein ${ }^{57}$ used Koussevitzky's score with Slonimsky's rebarring in the Danse sacrale when he guest-conducted the Boston Symphony in 1947 for his first performance of Le Sacre ${ }^{58}$ Bernstein sent a note to Slonimsky in April 1984, on the occasion of his ninetieth birthday:

Every time I conduct Le Sacre, as I did most recently two weeks ago (and always from Koussy's own score, with your re-barring), I admire and revere and honor you as I did the very first time [in 1947]..$^{59}$

Three full scores and a score for two pianos (four hands) annotated by Bernstein are available at the New York Philharmonic Leon Levy Digital archives. All three full scores (ID 2341, 2342, and 3623) include the re-barring by Slonimsky adding long vertical bar lines with red pencil and the new meters with blue colored stamp. All three scores are catalogued as B\&H 16333: either 1948 or 1965 edition (the corrected reprint of the1948 edition of Le Sacre). They confirm that Slonimsky's re-barring of these scores was copied from Koussevitzky's 1921 score. However, the NY Philharmonic Digital Achieves does not provide the original annotated score that Bernstein received from Koussevitzky and used in 1947. The following score (ID 2341) in Figure 3. shows Bernstein's note, "Re-barring by Nicholas Slonimsky (c.1924). LB" on page 112.

\footnotetext{
56 Ibid., 76.

57 A renowned American conductor (1918-1990), composer, pianist, author and educator. He was a music director of the New York Philharmonic from 1958-1969.

58 Olga Manulkina, "Leonard Bernstein's 1959 Triumph in the Soviet Union," The Rite of Spring at 100 (Bloomington: Indiana University Press, 2017), 221.

59 Nicholas Slonimsky, Perfect Pitch (Oxford: Oxford University Press, 1988), 76.
} 
Figure 3: The "Danse sacrale" in the score of Le Sacre that Bernstein used, with Bernstein's note about Slonimsky's re-barring. Leonard Bernstein Score Collection, ID 2341 (page 112). Courtesy of the New York Philharmonic Leon Levy Digital Archives.

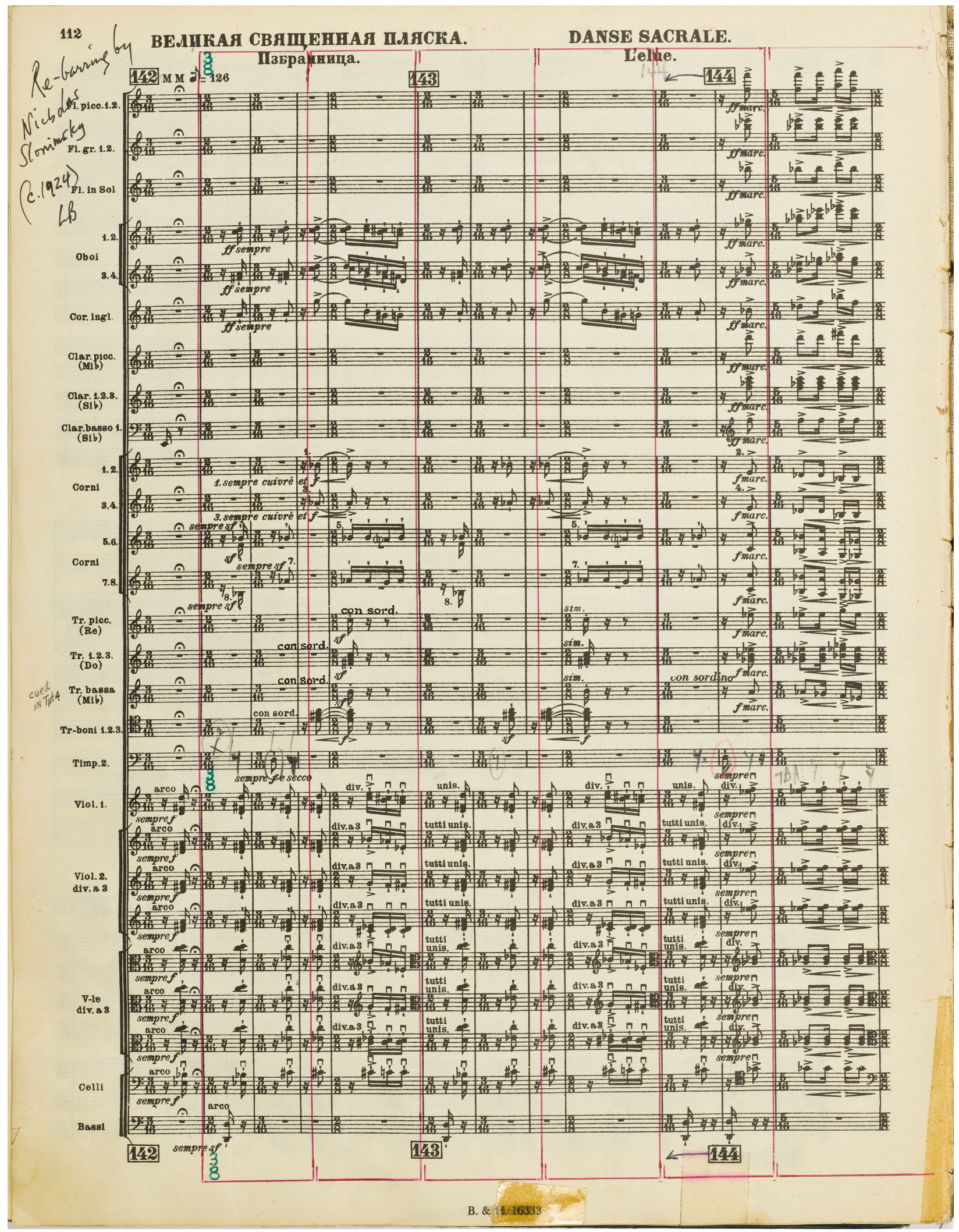


Slonimsky welcomed Stravinsky’s 1943-revised version of the Danse sacrale when it was published approximately twenty years after his own re-barring for Koussevitzky:

Some twenty years later Stravinsky himself published a simplified arrangement of Danse sacrale. Not being constrained to follow his original metrical divisions, he freely altered his syncopated textures. ${ }^{60}$

Slonimsky's re-barring of the Danse sacrale shares some similarity with portions of Stravinsky's own 1943 re-barring. In Example 4, the highlighted measures in 3/8 (Slonimsky's new meter in blue stamps) before no. 145 and no. 146, match with Stravinsky's 1943 re-barring in 3/4 measures (because Stravinsky doubled the basic note value to eighth note) in one measure before no. 5 and no. 6 in Example 5.

Stravinsky used the same procedure as Slonimsky's re-barring. Both of them combined the last two beats from the first measure with the following measure (in duple meter) to form a triple metered measure. However, he retained the original two-measure grouping (a syncopated triple meter plus double duple meter: ex. $3 / 16+2 / 8$ in the previous editions before 1943 , or $3 / 8+$ 2/4 in the 1943 revision) for all other places. However, Slonimsky's re-barring makes the triple meter by combining a beat into a duple meter consistently throughout the piece.

Like Slonimsky, Ansermet thought that re-barring would be effective. He wrote a letter to Stravinsky on May 23, 1957, yet again raising some questions about technical issues concerning part of the Danse sacrale:

At the third measure after no. 198, the basses and timpani, which until this point 'accompany' the melodic rhythm, now take a regular binary rhythm which dominates the other and against which the other forms syncopations. Since it is the very devil to obtain the exactitude of the basses in the unequal measures ... would it not be reasonable to notate the rhythm in this passage according to the rhythm of the basses? ${ }^{61}$

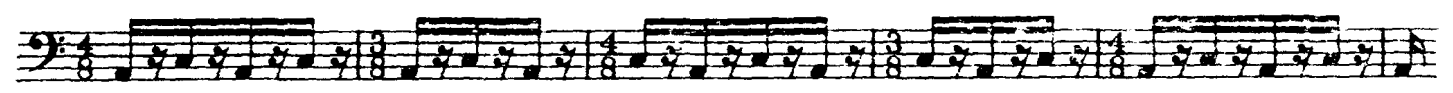

In fact, Ansermet's suggested re-barring is identical to Slonimsky's re-barring in the same section of the Danse sacrale (see Example 3 below).

EXAMPLE 3: Slonimsky's re-barring after no. 198 (Courtesy of the New York Philharmonic Leon Levy Digital Archives)

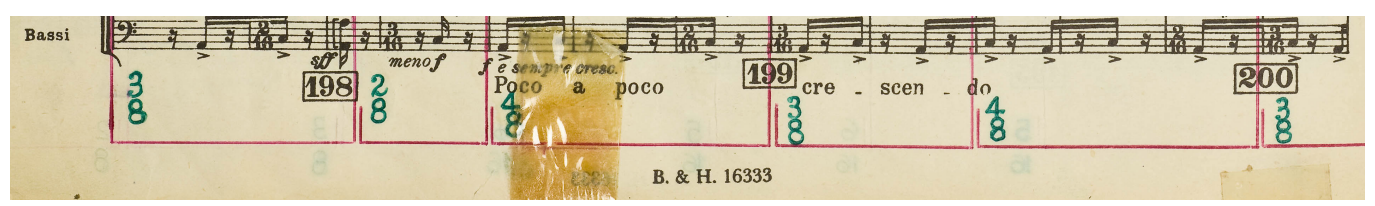

\footnotetext{
60 Nicholas Slonimsky, Perfect Pitch (Oxford: Oxford University Press, 1988), 76.

${ }^{61}$ Robert Craft, “Le Sacre du printemps: The Revisions,” Tempo 122 (1977), 8.
} 
EXAMPLE 4: The "Danse sacrale" in the score of Le Sacre that Bernstein used, with Bernstein's note about Slonimsky's re-barring. Leonard Bernstein Score Collection, ID 2341 (page 113). Courtesy of the New York Philharmonic Leon Levy Digital Archives.

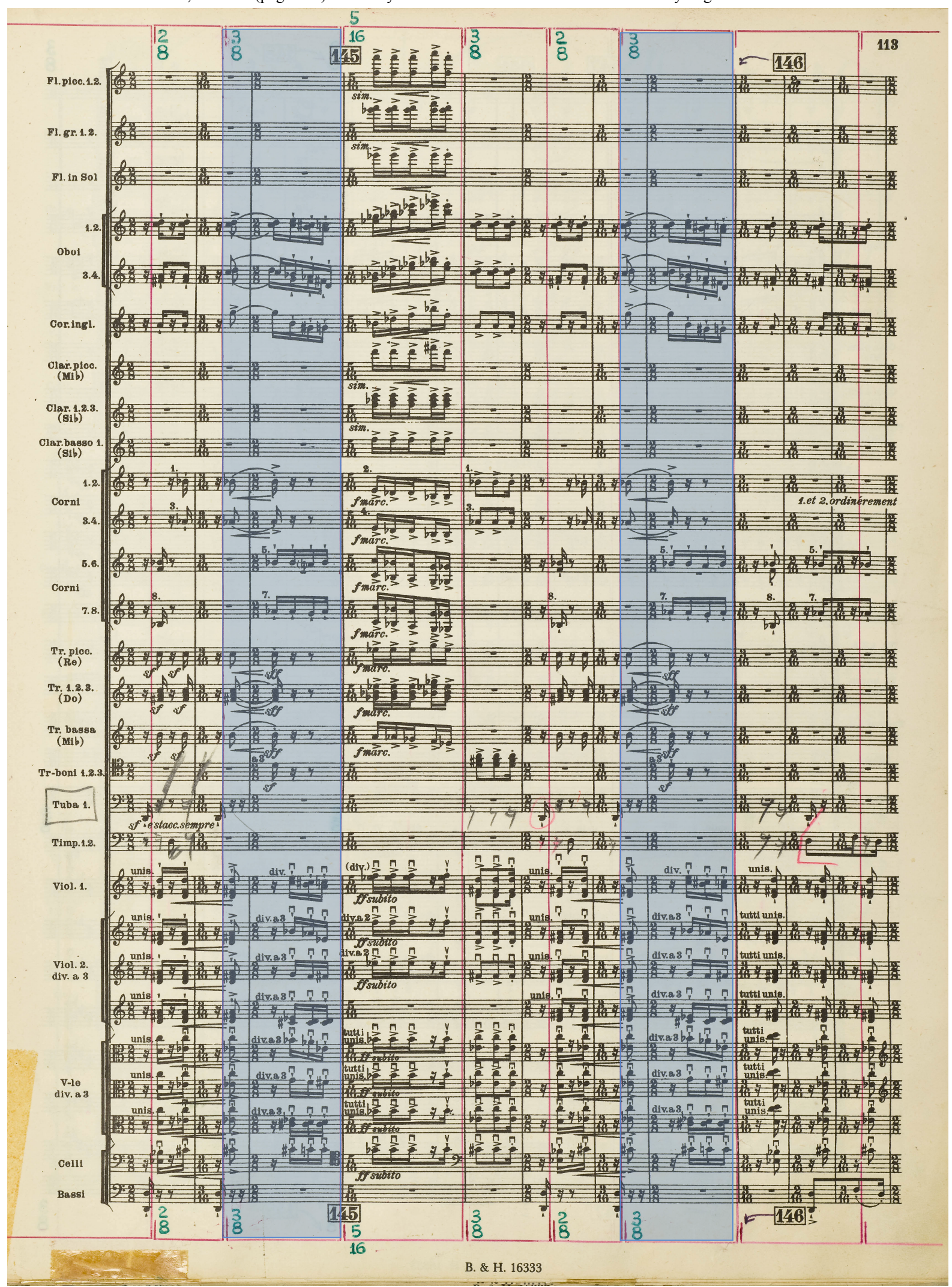


EXAMPLE 5: 1943-Revised Version of the "Danse sacrale," Copyright, 1945. By Associated Music Publishers, Inc.

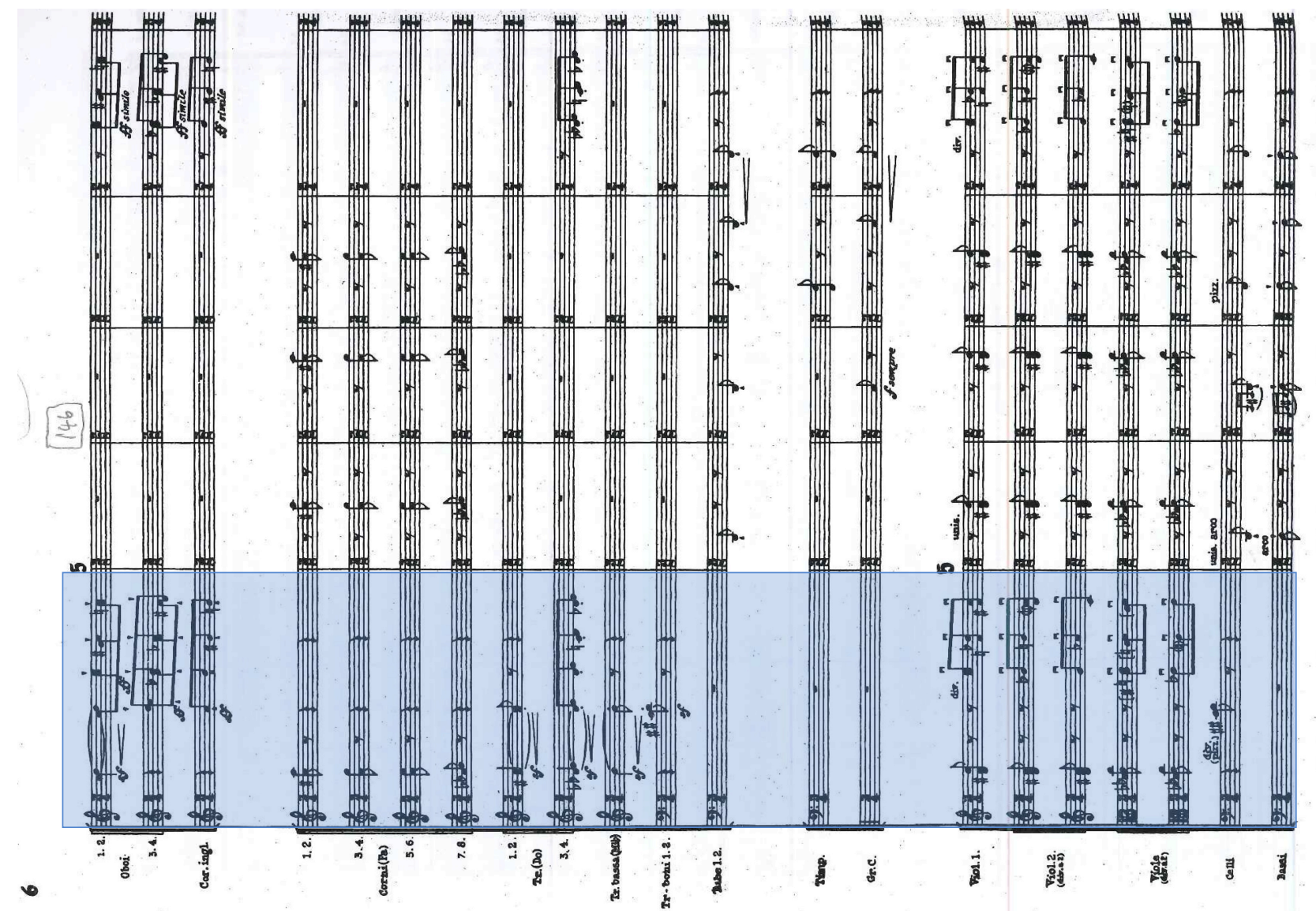

in
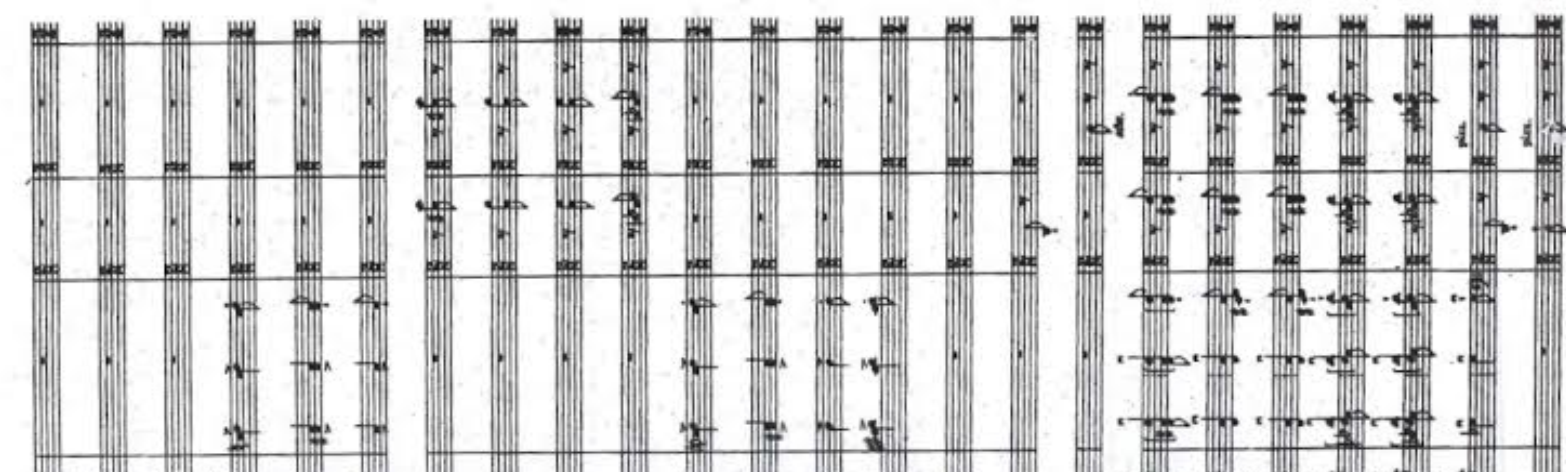

at

$+\infty \frac{-\infty}{-\infty}+\infty$

.

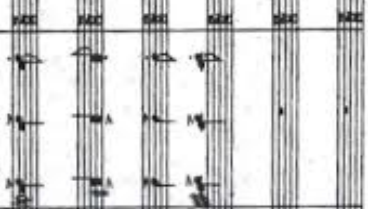

in

-

7.

$\cdots+\infty-\infty+\infty-\infty, \cdots$

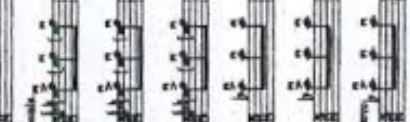

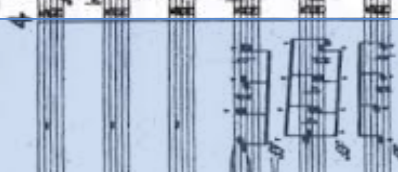

201

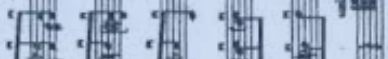

- (1) - 10

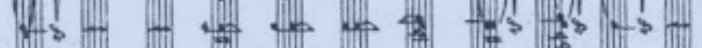

.

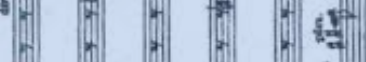

Tif

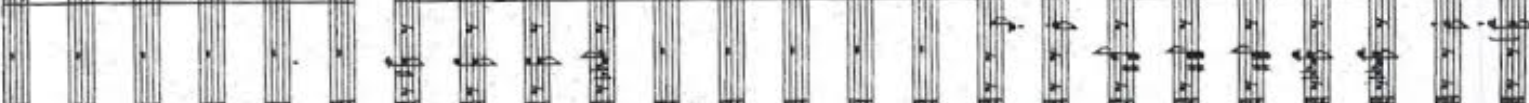

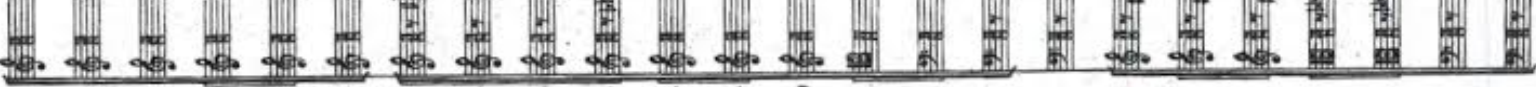

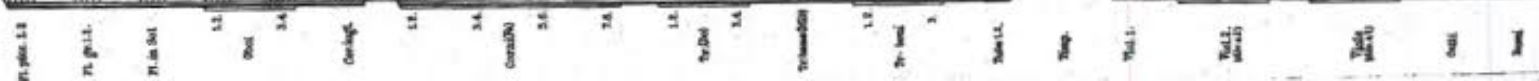


Slonimsky's re-barring helped Koussevitzky to overcome the great rhythmical challenges that Danse sacrale presents. It even benefitted the celebrated American conductor, Leonard Bernstein. However, it is interesting to observe Stravinsky's impression after he watched Bernstein's conducting the Danse sacrale with Slonimsky's re-barring. Stravinsky described it in his 1962 Moscow talk, reported in Sovetskaia muzyka in 1963:

\begin{abstract}
In the finale of my work one has to conduct in 3 and 5. This is not easy for a conductor. Bernstein makes his task easier by combining 3 and 5 and dividing the resulting 8 in two. If Craft and I can conduct in 3 and 5 , why is it that Bernstein does not want to master it? In making it easier for himself he makes it more complicated for the instrumentalists. ${ }^{62}$
\end{abstract}

Aside from the problem of making it "more complicated for the instrumentalists," Slonimsky's re-barring for the Danse sacrale presents a number of more fundamental issues. First, the whole rhythmic rhetoric is changed; upbeats become downbeats after the re-barring (see Example 6 below). Secondly, it changes the placement of syncopations notated by means of accents. By losing the sense of syncopation, which is one of the most essential rhythmic elements in the Danse sacrale, the intended rhythmic instability is ignored. After all, Slonimsky's re-barring is a distortion of the inherent rhythmic phrasing and accentuation that Stravinsky originally intended. Although it provided Koussevitzky with an invaluable aid for him to cover up his technical inadequacy, and Bernstein with convenience in dealing with the great rhythmical challenges, it should be considered something of a cheat. In using this rebarring, one loses the very essence of the rhythmic intensity and vitality that the original score of the Danse sacrale possessed.

EXAMPLE 6: Slonimsky's Re-barring at three measures before no. 145 and three measures after no. 145

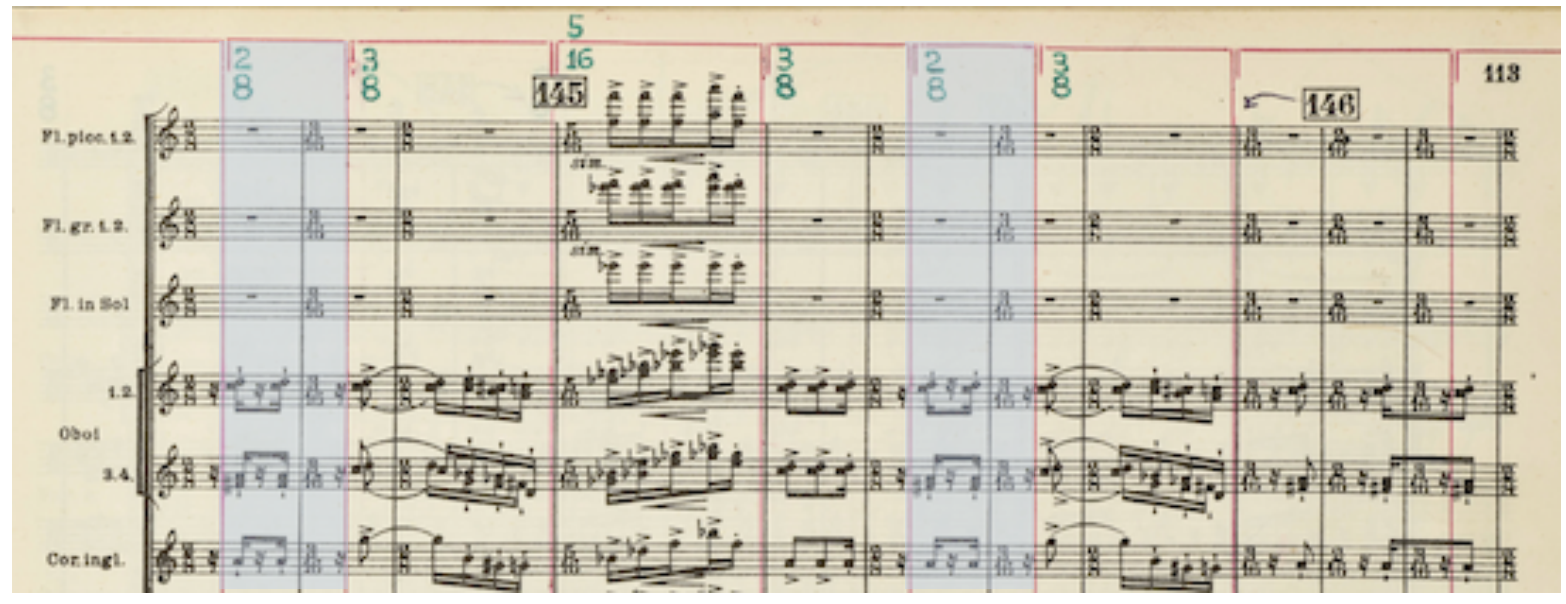

62 Olga Manulkina, "Leonard Bernstein's 1959 Triumph in the Soviet Union," The Rite of Spring at 100 (Bloomington: Indiana University Press, 2017), 224. 


\section{Chapter 4 \\ Rhythmic Analysis of Danse sacrale ${ }^{63}$}

Both Olivier Messiaen ${ }^{64}$ and his pupil, Pierre Boulez ${ }^{65}$ discussed and provided analyses of Le Sacre in their writings. In the second chapter of the Technique of My Musical Language, Messiaen includes four measures from the Danse sacrale from Stravinsky's Le Sacre du printemps as an example 1. He considered the Danse sacrale to be ametrical ${ }^{66}$ and that "Stravinsky, consciously or unconsciously, drew one of his most striking rhythmic procedures from the Hindu rhythm simhavikrîdita." ${ }^{, 67}$ Although Messiaen's discussion of the Danse sacrale is interesting and refreshingly insightful, it is not relevant to my study of the piece since his analysis takes a different approach based on Hindu rhythm.

In the second chapter ("Stravinsky Remains") of his book of essays, Notes of an Apprenticeship ${ }^{68}$ Boulez wrote an extensive and detailed analytical essay of Le Sacre covering the major movements of Stravinsky's whole ballet score, and particularly in great detail, the Danse sacrale. Following Boulez's analysis as a model (but not limited to, and with some modifications in terminology and labeling), this chapter will provide an in-depth analysis of the Danse sacrale. The method of the analysis is based on Boulez's rhythmic cell technique, "the juggling of bars or pairs of bars." ${ }^{, 69}$

The impression when one encounters the score of the Danse sacrale for the first time might be overwhelming with the perpetual changes of meters; meters change in every or every other measure in the first section (A section) of the Danse sacrale (no. 142-149). ${ }^{70}$ Although it seems perplexing and completely irregular, there exists a sense of coherent flux and repetition of rhythmic units, and symmetries. Two concepts need to be introduced for the analysis: Rhythmic

\footnotetext{
${ }^{63}$ In this analysis, Dover edition was used: Reprint of the Izdatel'stvo "Muzyka," Moscow, 1965 edition. Rehearsal numbers match with other editions such as B\&H and Kalmus. To follow this analysis, a copy of the score is necessary.

64 A French composer (1908-1992) who was a professor of composition in the Paris Conservative (1966-78). Pierre Boulez and Karlheinz Stockhausen are the most notable of his numerous students.

65 A French composer (1923-2016), conductor and writer. He was one of the most prominent pupils of Olivier Messiaen.

${ }^{66}$ Without fixed meter, lacking a regular, sustained pulse (Webster's New World, Dictionary of Music), 10.

67 Olivier Messiaen, Technique of My Musical Language (Paris: Alphonse Leduc, 1956), 14.

68 Pierre Boulez, Notes of an Apprenticeship (New York: Alfred A. Knopf, 1968), 72-145.

69 Peter Hill, Stravinsky: The Rite of Spring (Cambridge: Cambridge University Press, 2000), 55.

70 All numbers indicate rehearsal numbers in the score.
} 
cell and Rhythmic phrase. Boulez sometimes uses these two terms synonymously in his essay but these will be distinguished in this analysis.

Rhythmic cell can be a single or combined rhythmic unit to form a rhythmic syntax. It can be identified in two ways:

(1) By identifying a single independent unit or pairing/combining the two or more rhythmic units that later reappear in the same grouping: Ex. rhythmic cells in the A section (no. 142-149).

(2) By the beams that connect more than two note heads (often crossing over the bar lines) in the B section (no. 149-167) and Coda II (no. 186-201).

Rhythmic phrase consists of two or more rhythmic cells combined.

The large-scale structure of the Danse sacrale is [A - B - A - Coda I - Coda II].

The author presents the outline of the overall formal scheme is as follows:

- A section: consists of three periods.

- First period: no. 142-144

- Second period: no. 144-146

- Third period: no. 146-149

- B section: consists of six periods. ${ }^{71}$

- First period: no. 149-154

- Second period: no. 154-156

- Third period: no. 156-159

- Fourth period: no. 159-162

- Fifth period: no. 162-165

- Sixth period: no. 165-167

- Return of A section: "a textual reprise of the first" 72 transposed a half step lower.

- First period: no. 167-169

- Second period: no. 169-171

- Third period: no. 171-174

\footnotetext{
${ }^{71}$ B section differs from A section in terms of rhythm, harmony, texture and orchestration. Most notably, rhythmic cells in B section are identified by the beams that connect and group the note heads.

72 Pierre Boulez, Notes of an Apprenticeship (New York: Alfred A. Knopf, 1968), 124.
} 
- Coda I: no. $174-186 .^{73}$ With an interpolation of $[\Gamma 12+\Gamma 6]^{74}$ from the A section. Peter Hill calls it flashback: "it is both a caesura- a momentary catching of the breath from which the storm resumes with even greater fury- and a 'window' which renews contact with the opening music of the Danse sacrale." 75

-Coda II: consists of two sections.

Section I: consists of three periods.

- First period: no. 186-189

- Second period: no. 189-190

- Third period: no. 190-192

Section II: consists of two periods.

- First period: no. 192-196

- Second period: no. 196-201

Table 3. Labeling of the rhythmic structure in the Danse sacrale

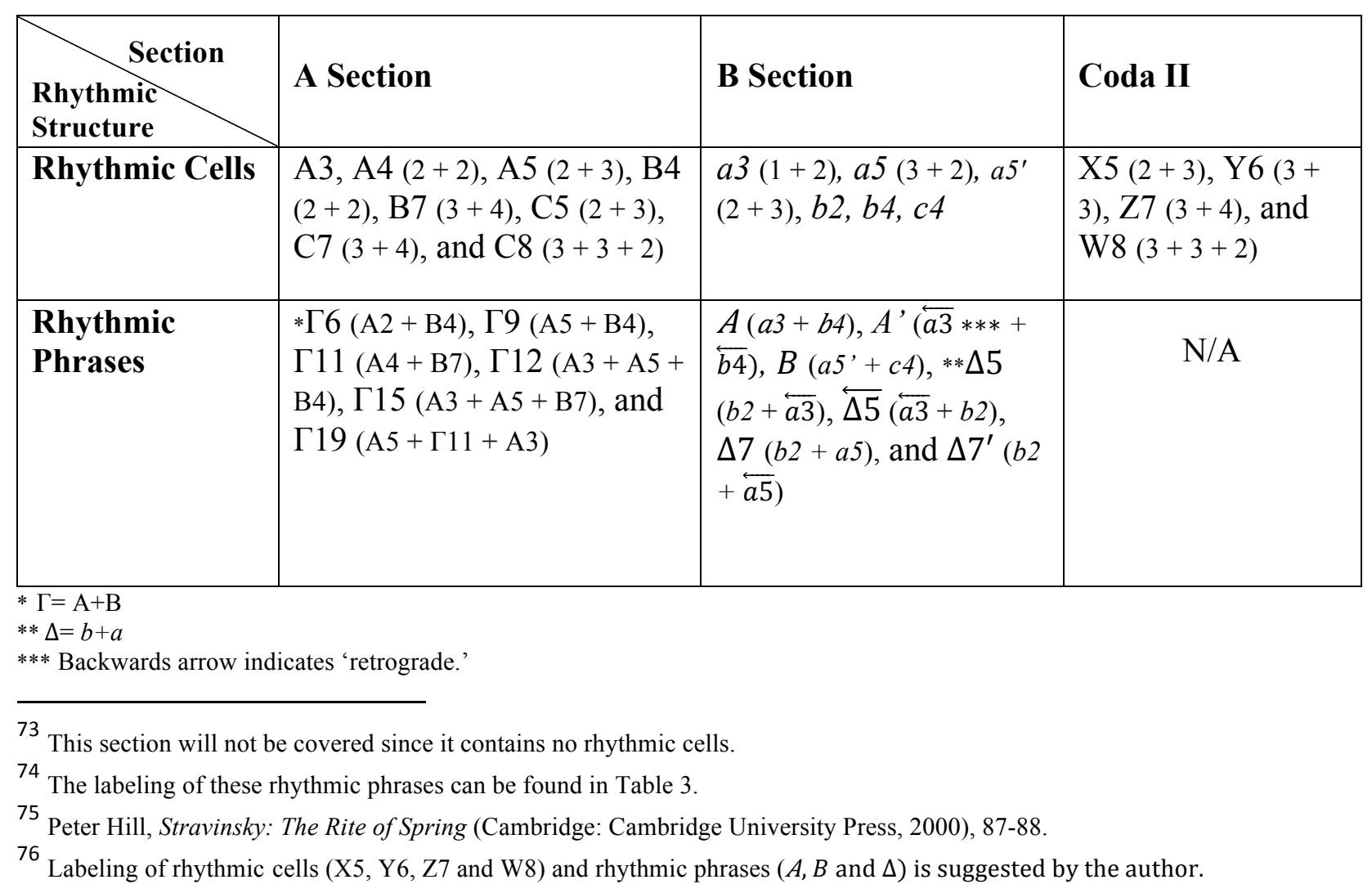




\section{Detailed Analysis of the A section and Coda II.}

Boulez provides a thorough rhythmic cell analysis in detailed schemas for both the A and B sections as well as Coda II.

EXAMPLE 7: Boulez's Rhythmic Schema for the A section of Danse sacrale
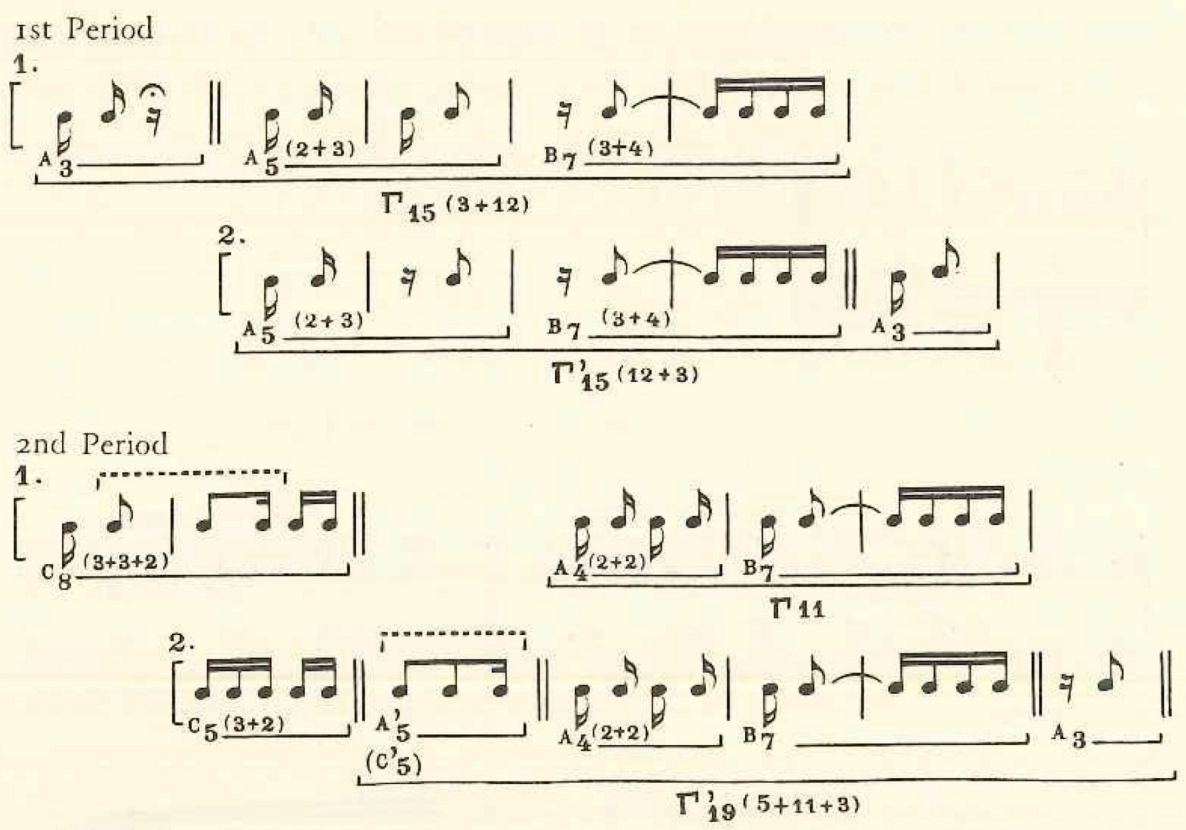

3rd Period

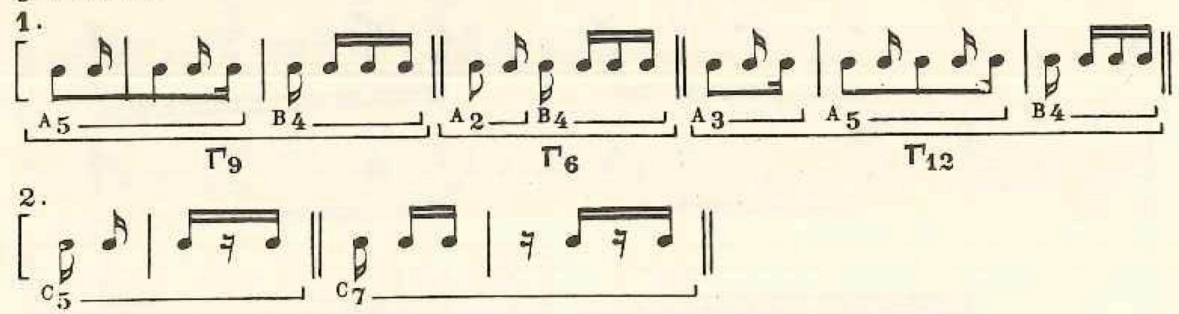

As shown in the Example 7, rhythmic cells in the A section are A3, A4 $(2+2),{ }^{78}$ A5 $(2+$ 3: originally $3+2)$, B4 $(2+2),{ }^{79} \mathrm{~B} 7(3+4), \mathrm{C} 5(2+3), \mathrm{C} 7(3+4)$, and C8 $(3+3+2)$. Rhythmic phrases in the A sections are Г6 (A2 + B4), Г9 (A5 + B4), Г11 (A4 + B7), Г12 (A3 + A5 + B4), $\Gamma 15(\mathrm{~A} 3+\mathrm{A} 5+\mathrm{B} 7)$, and $\Gamma 19(\mathrm{~A} 5+\Gamma 11+\mathrm{A} 3)$. There are two factors that identify rhythmic cell A5. First, we have already seen from the sketchbook of Le Sacre (see Example 8 below) that Stravinsky originally intended the second measure in the beginning of the Danse sacrale to be an

\footnotetext{
77 Pierre Boulez, Notes of an Apprenticeship (New York: Alfred A. Knopf, 1968), 126.

78 A4 can be seen in Example 4 on page 20 (three measures before no. 145 and three measures after no. 145).

${ }^{79}$ B4 can be seen in Example 4 on page 20 (on measure before no. 145 and two measures after no. 146).
} 
asymmetrical meter of 5/8 $(3+2)$, which later he separated into two measures: $[2 / 16+3 / 16]$ in RMV 196, 197, and [3/8 + 2/8] in the 1943 revised version.

EXAMPLE 8: Sketchbook, $p .84^{80}$

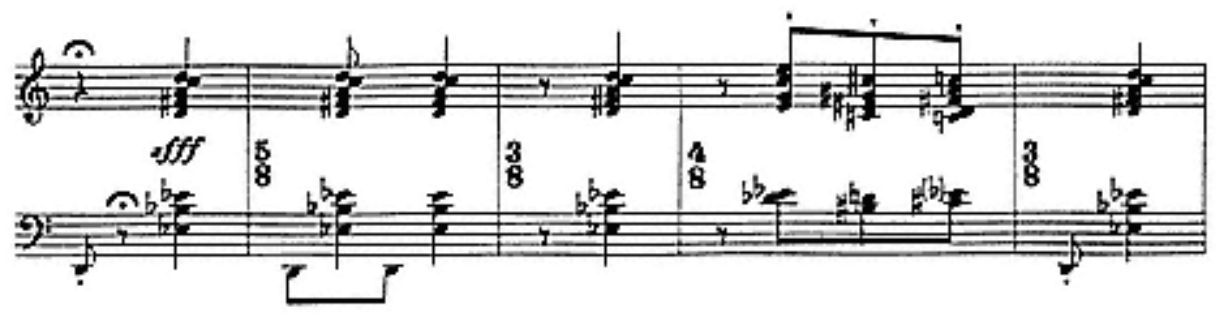

Second, A5 reappears three times at no. 146 (with a beam in the basses and timpani: $2+3$ ), the second and the third measures of no. 147 (appearing the same as in no. 146), and at no. 186 $(5 / 16: 2+3)$.

In the first period (no. 142-144), A3 has a framing function. Following the first A3, the four-measure phrase $(\mathrm{A} 5+\mathrm{B} 7)$ can be labeled with $\Gamma 12 . \Gamma 12$ is then repeated (exact repetition). Now, the first period can be viewed as a symmetrical structure as follows:

$$
\mathrm{A} 3 / / \Gamma 12(\mathrm{~A} 5+\mathrm{B} 7) / \Gamma 12(\mathrm{~A} 5+\mathrm{B} 7) / / \mathrm{A} 3
$$

In the second period (no. 144-146), C8 can be separated into C3 + C5; C3 is the transfiguration of A3 with different harmony and more intensity, preceding the powerful $\mathrm{C} 5$. The second period is also in a symmetrical structure with an interpolation of A5 (as highlighted below) in the second statement.

$$
\begin{aligned}
& \mathrm{C} 3 / / \text { 1. } \mathrm{C} 5(3+2) \quad / \Gamma 11(\mathrm{~A} 4+\mathrm{B} 7) \\
& \text { 2. } \mathrm{C} 5(3+2) / \mathrm{A} 5 / \Gamma 11(\mathrm{~A} 4+\mathrm{B} 7) / / \mathrm{A} 3
\end{aligned}
$$

The third period (no. 146-149) consists of two statements. Statement I is, in fact, symmetrical and the new grouping with equal proportion is highly recommended.

- Boulez's division: $\Gamma 9$ (A5 + B4) / Г6 (A2 + B4) / Г'12 (A3 + A5 + B4)

- New division: $\Gamma 9(\mathrm{~A} 5+\mathrm{B} 4) / \Gamma 9(\mathrm{~A} 2+\mathrm{B} 4+\mathrm{A} 3) / \Gamma 9(\mathrm{~A} 5+\mathrm{B} 4)^{82}$

\footnotetext{
${ }^{80}$ Pieter C. van den Toorn, Stravinsky and The Rite of Spring (Berkeley: University of California Press, 1987$), 55$.

${ }^{81} \Gamma^{\prime} 12(3+2+3+4)$ shares the identical rhythmic phrase structure with the beginning four-measure phrase after the fermata in the 1943-revised version.

82 Suggested by the author.
} 
Boulez labeled two rhythmic cells as C5 and C7 in the Statement II. However, this author found it necessary to change the labeling in order to introduce new rhythmic cells in the Statement II since these two rhythmic cells do not share any similarities to the previous rhythmic cell C.

In fact, they present completely different identities, which will reappear in the Coda II.

Therefore, the author suggests new schemas for the third period is as follows:

- Statement I: Г9 (A5 + B4) / Г9 (A2 + B4 + A3) / Г9 (A5 + B4)

- Statement II: X5 $(2+3) / Z 7(3+4)$

As previously mentioned, the reprise of the A section is textually an exact repetition, but transposed a half step lower than the first time. Analysis for 'Coda I' will not be covered because this section contains no rhythmic cells.

It will be logical to continue with the rhythmic cell analysis of Coda II (no. 186-201) since it shares the same rhythmic cells from the A section of the Danse sacrale. Coda II consists of two sections. The first section (no. 186-192) includes three periods.

EXMAPLE 9: Boulez's Rhythmic Schema for the first section of the Coda II of Danse sacrale P3 $^{83}$
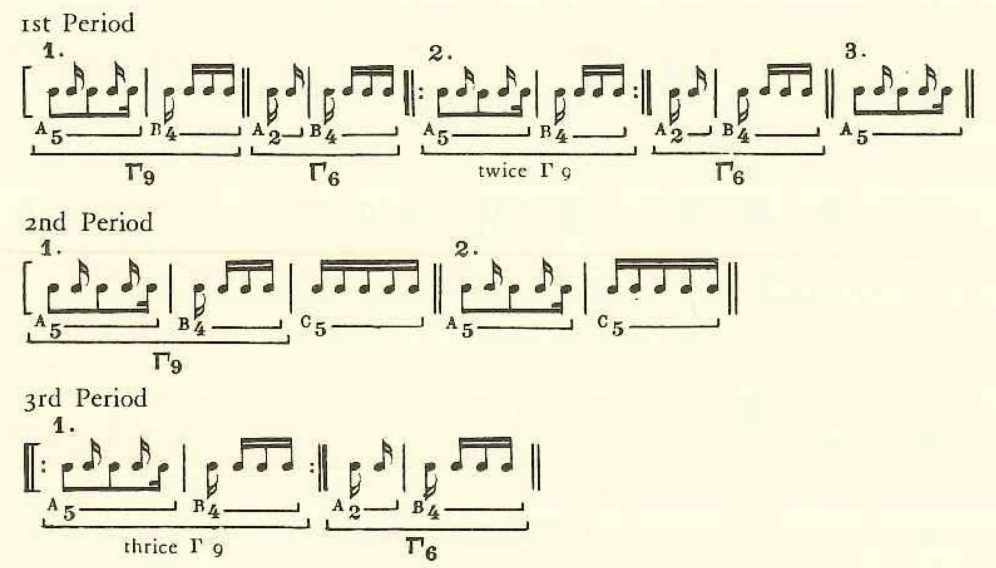

All three periods include $\Gamma 9$. The first statement of the first period is comprised of a simple Antecedent (Г9) and a Consequent (Г6). The second statement shows the repetition of the Antecedent followed by the Consequent with an addition of A5 (as highlighted below).

83 Pierre Boulez, Notes of an Apprenticeship (New York: Alfred A. Knopf, 1968), 133. 
The second period starts with $\Gamma 9$, but then it brings back the $\mathrm{C} 5$ cell, which is mirrored around A5 in the middle. In the third period, the $\Gamma 9$ is repeated three times; in other words, the further expanded Antecedent is followed by the same Consequent as in the first period.

The schemas for the first section of Coda II (see Example 9 above) are as follows:

- First period: $1 . \Gamma 9(\mathrm{~A} 5+\mathrm{B} 4)$

$/ / \Gamma 6(\mathrm{~A} 2+\mathrm{B} 4)$

2. Г9 (A5 + B4) / Г9 (A5+ B4)

// Г6 (A2 + B4) // A5 (added)

- Second period: $\quad \Gamma 9(\mathrm{~A} 5+\mathrm{B} 4)$

// C5 A5 C5

- Third period: $\quad$ Г9 (A5 + B4) / Г9 (A5 + B4) / Г9 (A5 + B4) // Г6 (А2+ B4)

The second section of the Coda II (no. 192-201) contains new rhythmic cells (X5 and Z7 made an earlier appearance at the end of the A section): X5 $(2+3)$, Y6 $(3+3), Z 7(3+4)$, and $\mathrm{W} 8(3+3+2)$, thus having all numbers from 5 to 8 . It also includes $x 5, y 6, z 7$, and $w 8$ functioning as echoes of X5, Y6, Z7, and W8. Section II of Coda II has two periods.

- First period: $\quad \mathrm{X} 5 / x 5 / \mathrm{Y} 6 / / x 5 / x 5 / y 6 / x 5 / w 8 / / \mathrm{X} 5 / y 6$

- Second period: $\quad$ X5 / Y6/Z7/W8 // X5 / W8 // Y6/W8 / Y6 / W8 // C5

Unlike the previous section, section II shows little sense of symmetry or coherent sense of repetition. For the first period, Boulez grouped rhythmic cells in terms of alternating between the big cells and small cells: the first fragment (X5 / $x 5$ / Y6) and the third fragment (X5 / y6) or non-alternating (the second fragment: $x 5 / x_{5} / y 6 / x 5 / w 8$ ). In the second period, one can observe the progressively increasing number of beats in the first fragment (X5 / Y6 / Z7 / W8); jumping directly from the minimum to the maximum in the second fragment (X5 / W8); an alternation of 6 and 8 in the third fragment (Y6 / W8 / Y6 / W8); followed by the final statement of $5^{84}$

84 Pierre Boulez, Notes of an Apprenticeship (New York: Alfred A. Knopf, 1968), 133-134. 


\section{Detailed Analysis of the $B$ section.}

In the B section of the Danse sacrale (no. 149-162), all rhythmic cells are governed by the beams that connect and group the note heads either in a single or in double/triple measures. Rhythmic cells in the B section are $a 3(1+2), a 5(3+2), a 5^{\prime}(2+3),{ }^{85} b 2, b 4, c 4 ; a 5^{\prime}, b 2$ and $c 4$ are non-retrogradable. Rhythmic phrases in the B sections are $A(a 3+b 4), A^{\prime}(\overleftarrow{a 3}+\overleftarrow{b 4}), B\left(a 5^{\prime}\right.$ $+c 4), \Delta 5(b 2+\overleftarrow{a 3}), \overleftarrow{\Delta 5}(\overleftarrow{a 3}+b 2), \Delta 7(b 2+a 5)$ and $\Delta 7^{\prime}(b 2+\overleftarrow{a 5})$. B section contains six periods. The first, second, fourth and the fifth periods are built primarily on a single chord whereas the third and the sixth periods are modulating on three chords.

EXAMPLE 10: Boulez's Rhythmic Schema for the B section of Danse sacrale ${ }^{86}$
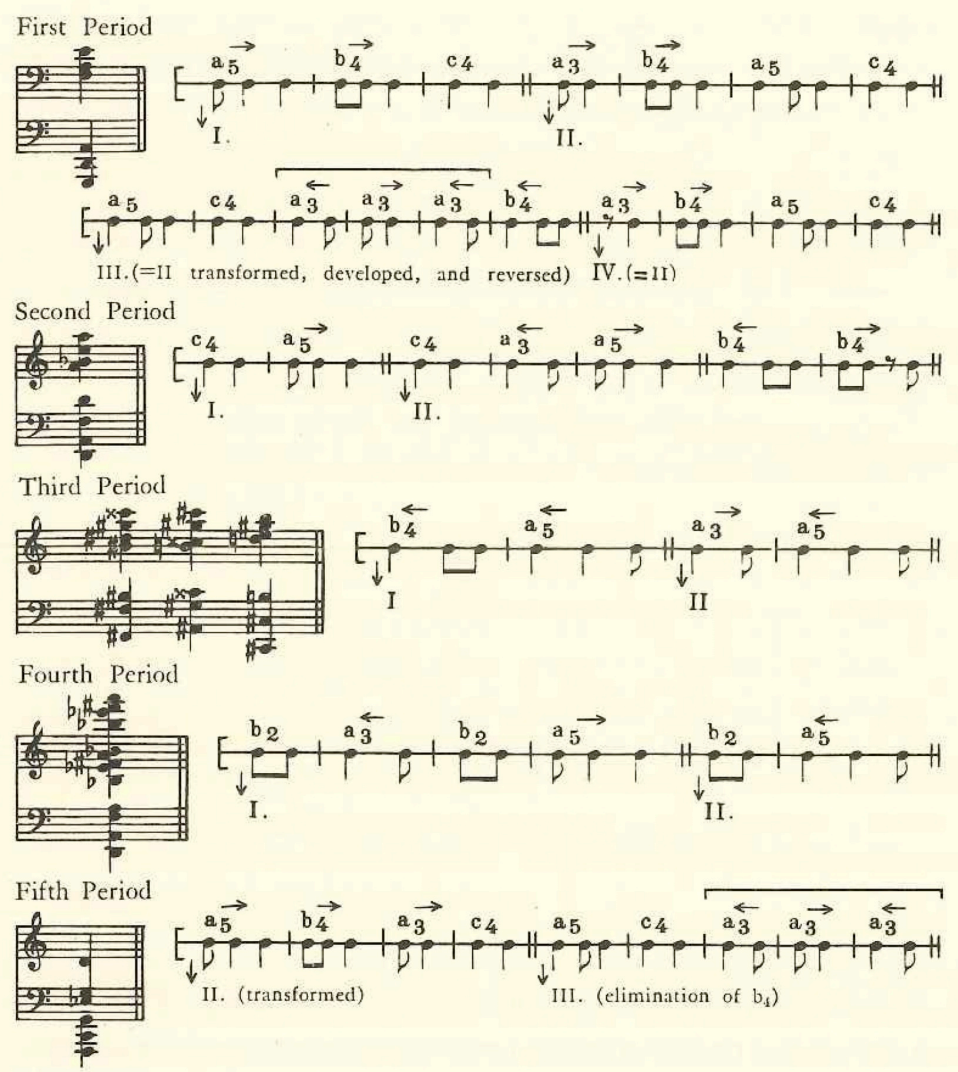

Sixth Period
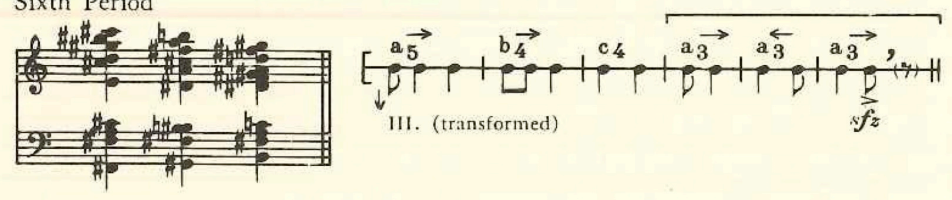

85 Boulez did not differentiate $a 5(3+2)$ from $a 5^{\prime}(2+3)$, but it is necessary to label them differently in order not to confuse them with one another, and to more accurately identify $a 5$, a5 retrograde and $a 5^{\prime}$. $a 5^{\prime}$ ' is a non-retrogradable rhythm.

${ }^{86}$ Pierre Boulez, Notes of an Apprenticeship (New York: Alfred A. Knopf, 1968), 93. The harmonic structures are not being considered in this author's analysis. 
The first period (no.149-154) consists of four fragments. Three basic rhythmic cells are introduced in fragment I. Fragment II is a transformation of fragment I; a5 transformed to $a 5$, and truncated to $a 3$. Fragment III is further transformed from fragment II; the rhythmic phrases $A$ and $B$ reverse in their positions with $a 3, b 4$ being retrograded. Also, $\stackrel{4}{a 3} a 3]^{87}$ are interpolated between the two rhythmic phrases. Fragment IV is the exact repetition of fragment II.

EXAMPLE 11: Boulez's Rhythmic Schema for the first period of the B section of Danse sacrale ${ }^{88}$

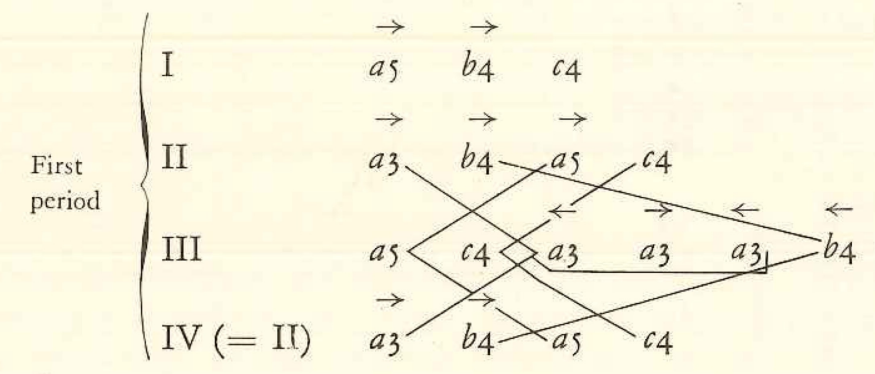

EXAMPLE 12: New schema for the first period of the B section of Danse sacrale ${ }^{89}$

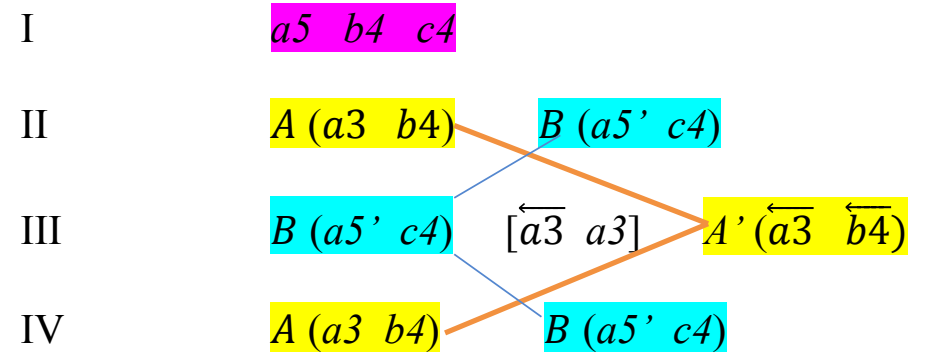

The second period (no. 154-157) contains three fragments in the following schema.

$\begin{array}{lll}\text { I } & c 4 & a 5^{90} \\ \text { II } & c 4[\overleftarrow{a 3}] & a 5 \\ \text { III } & \overleftarrow{b 4} & a 4^{91}\end{array}$

\footnotetext{
87 Backwards arrow indicates 'retrograde.'

88 Pierre Boulez, Notes of an Apprenticeship (New York: Alfred A. Knopf, 1968), 94.

${ }^{89}$ Boulez provided a schema (Example 11), however a new schema (Example 12) is necessary for the new labeling for $a 5^{\prime}$ and two rhythmic phrases $A(a 3 \quad b 4)$ and $B\left(a 5^{\prime} c 4\right)$.

90 Boulez labeled it as $\overleftarrow{a 5}$ but in this author's opinion, $a 5$ would have been accurate.

${ }^{91}$ Boulez labeled it as $b 4$, but the cell more resembles to $a 5$. Thus, this author suggests labeling it as $a 4$ (truncated version of $a 5$ ).
} 
The second fragment is the repetition of fragment I with an interpolation of $\overleftarrow{a 3}$. The third fragment contains two transformed rhythmic cells: the retrograde of $b 4$, and the truncated $a 5$.

The third period (no. 157-159) consists of two fragments, both of which contain all retrograded cells.

$$
\begin{array}{lll}
\text { I } & \overleftarrow{b 4} & \overleftarrow{a 5} \\
\text { II } & \overleftarrow{a 3}^{92} & \overleftarrow{a 5}
\end{array}
$$

The fourth period introduces a new rhythmic cell, non-retrogradable $b 2$ ("can be either the diminution of $c 4$ or the elision of $b 4 ")^{93}$ functioning as an anacrusis to the following cells: $\overleftarrow{a 3}, a 5$ and $\overleftarrow{a 5}$. Thus, three new rhythmic phrases can be identified.

$$
\begin{array}{ll}
\text { I } & \Delta 5(b 2+\overleftarrow{a 3}) \\
\text { II } & \Delta 7(b 2+a 5)^{94} \\
\text { III } & \Delta 7^{\prime}(b 2+\overleftarrow{a 5})
\end{array}
$$

The fifth period (no. 162-165) is the first reprise of the first period. It consists of two corresponding fragments from the first period: fragment $\mathrm{I}$, with an interpolation of $a 3$, that is now delayed by an eighth rest, and fragment III with the elimination of $\overleftarrow{b 4}$.

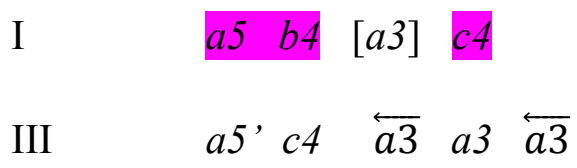

The sixth period (no. 165-167) is the second reprise of the first period. Similar to the fifth period, it consists of two corresponding fragments from the first period: the exact fragment I, and the truncated form of the later portion of the fragment III, which includes the retrograde of the $\Delta 5$ from the first fragment of the fourth period.

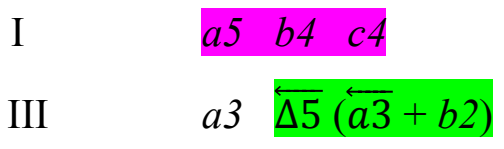

\footnotetext{
92 Boulez labeled it as $a 3$ but in this author's opinion $\overleftarrow{a 3}$ would have been accurate.

93 Pierre Boulez, Notes of an Apprenticeship (New York: Alfred A. Knopf, 1968), 95.

94 Boulez labeled it as $\overleftarrow{a 5}$ but in this author's opinion $a 5$ would have been accurate.
} 
The large-scale structure of the B section of the Danse sacrale (dealing with only rhythmic themes not harmonic content) follows the basic scheme of the monothematic sonata form. The layout can be summarized as follows:

- Exposition: The first period (no. 149-154)

- Development: The second, third and the fourth periods (no. 154-162)

- Recapitulation: The fifth and the sixth periods (no. 162-167)

Boulez's rhythmic cell analysis helps musicians to understand Stravinsky's complex rhythmic vocabulary and syntax of the Danse sacrale. As we have been exploring the rhythmic structure of the Danse sacrale in detail, grasping the sense of rhythmic evolution from the smallest units of duple and triple, forming rhythmic cells, then rhythmic phrases, then periods, then eventually large sections, has been the key for this particular analysis. We also witnessed that the process of the rhythmic evolution allows the balanced rhythmic fluctuation in the Danse sacrale. An equilibrium in the rhythmic structure in the Danse sacrale has been achieved both in smaller units and larger forms by "the play of the rhythmic symmetries" 95 in the A section, the transformations of rhythmic cells, and the play with variations of rhythmic phrases in the B section.

The rhythmic cell analysis of the Danse sacrale can also greatly contribute to the conducting of the piece: instead of conducting bar by bar, it helps the conductor to find the correct bar groupings which offer important clues when conducting the rhythmic cells. For example, in the first five measures of the Danse sacrale, by being able to identify the rhythmic cells (A3, A5 and B7), it reveals conducting patterns for each rhythmic cell. For example, A5 is in an asymmetrical two beat pattern $(2+3)$; the second measure in $2 / 16$ serves as an anacrusis to the following measure in $3 / 16$. This enables conductors to determine how to conduct more efficiently without having to beat one per measure. Another example is from no. 196 to no. 198 where the number of beats in each rhythmic cell is in increasing values: X5-Y6-Z7-W8. The conductor can easily grasp the layout of these rhythmic cells. Identification of the rhythmic cells provides as significant aid for conductors to formulate conducting patterns that are applicable to each rhythmic cell.

95 Pierre Boulez, Notes of an Apprenticeship (New York: Alfred A. Knopf, 1968), 89. 


\section{Chapter 5}

\section{A Conductor's Perspective: Considerations for conducting the Danse sacrale}

Conducting a piece like Le Sacre du printemps is a daunting task for any conductor. In the previous chapters, we witnessed how Koussevitzky struggled when he had to conduct Le Sacre. Similarly, Stravinsky had trouble when he conducted it. The challenges for conducting Le Sacre come from not only the technical aspects of dealing with the metrical changes and the complex rhythmic structures, but also the new aesthetic language Stravinsky introduced.

To understand a composer's musical language or style, a conductor or a performer must grasp the composer's musical characteristics and investigate all possible information on the background of the works and all possible evidence of the performance practices. We have already explored quite extensively the complicated and continuous revision process for Le Sacre.

However, it also presents an equally complicated history of performance practice. Since Stravinsky revised the score of Le Sacre over the course of half a century, it is hard to consider that the earlier historical performance practice is more authentic than the latter. In other words, the evolution of the score of Le Sacre constantly renewed expectations in performance practice. For instance, Monteux's 1913 première performance differed greatly from the way Stravinsky himself conducted the piece for the first time in 1926. Even though Stravinsky was present in the 1913 première, one cannot assume that the performance was more authentic than the later performance conducted by the composer.

Although there are no recordings available for the 1913 première performance of Le Sacre, the early performing materials including the 1913 autograph full score are available to investigate. The 1913 autograph full score contains markings with blue and red pencils. Volker Scherliess assumes that most of the performers' markings in the autograph full score are by Monteux. $^{96}$

By examining Monteux's score markings, we have some evidence of what tempos he took and what subdivisions of the asymmetrical meters of five and seven he used for the early performances of Le Sacre. Moreover, Robert Fink argues that Monteux's subdivisions for the asymmetrically metered measures contributed greatly to Stravinsky's re-barring of the 1929

\footnotetext{
${ }^{96}$ Robert Fink, "Rigoroso $(\delta=126)$ ": "The Rite of Spring" and the Forging of a Modernist Performing Style, Journal of the American Musicological Society, Vol. 52, No. 2 (Summer, 1999), 315.
} 
revision (see Example 14 on page 36). ${ }^{97}$ After the 1929 revision, the second measure in 5/16 became separated into $2 / 16+3 / 16$. As discussed in chapter 2 , simplifying the asymmetrically metered measures into single measures of two or three beats offers an immediate advantage for conducting and performing. Stravinsky went so far as to claim that the difficulty of conducting Le Sacre is actually no more than managing the simple alternation of twos and threes. ${ }^{98}$

However, Stravinsky did not separate 5/16 measures at the second measure of no. 144 and no. 145 in the Danse sacrale. Monteux's annotations for these measures indicate the groupings of $2+3$. Stravinsky shows clearly his intention for grouping these measures to be $3+$ 2, and corrects Monteux's wrong divisions of five in the 1929-revised version (see Example 13).

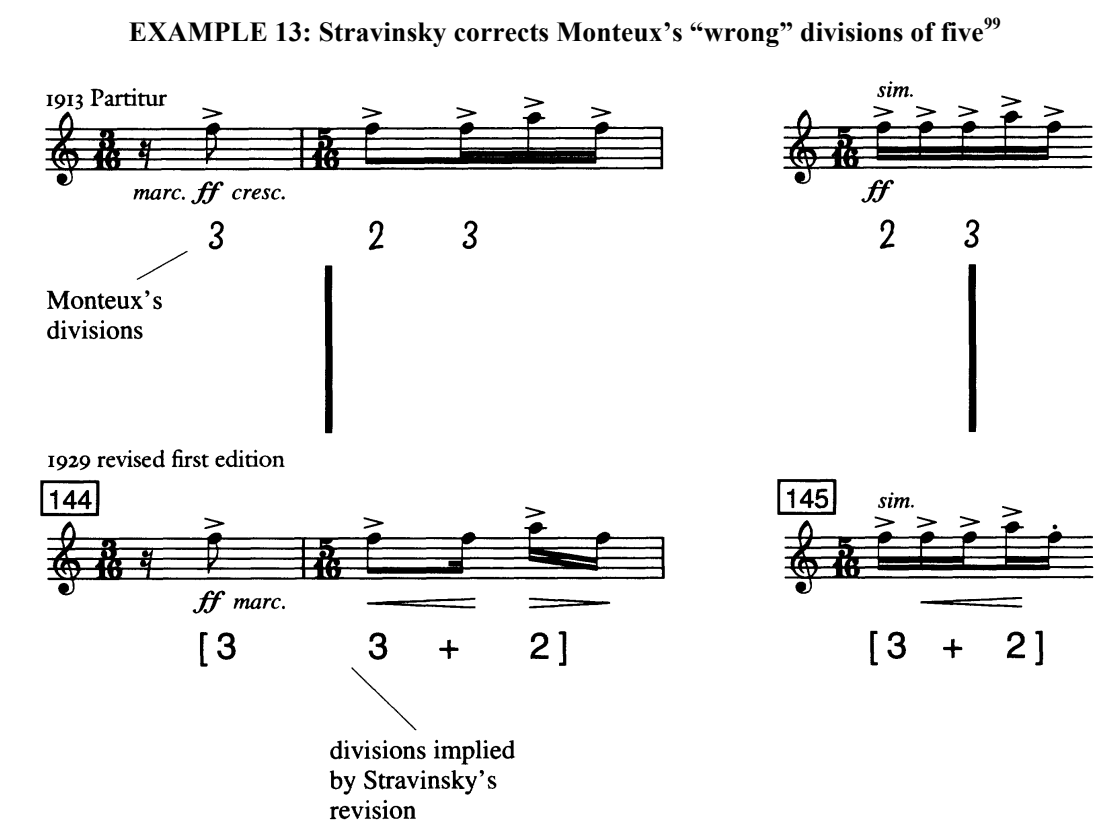

The new notation presents the divisions of $3+2$ in both measures. The rationale that Stravinsky grouped $3+2$ in these measures was to accentuate the note $A$ to emphasize the melodic contour. Subsequently, Stravinsky revised two things. First, he changed the articulation markings by eliminating the accents on the second and the third note $F$ from the second measure of no. 144 and changing the accent to staccato on the last note $F$ at no. 145. Second, he added crescendo-decrescendo at the second measure of no. 144, and a crescendo at no. 145.

\footnotetext{
97 Ibid., 318.

98 Stravinsky and Craft, Expositions and Developments (New York: Doubleday, 1962), 145.

99 Robert Fink, "Rigoroso $(\delta=126)$ ": "The Rite of Spring" and the Forging of a Modernist Performing Style, Journal of the American Musicological Society, Vol. 52, No. 2 (Summer, 1999), 322.
} 
EXAMPLE 14: Monteux and Stravinsky rebar the "Danse sacrale"100
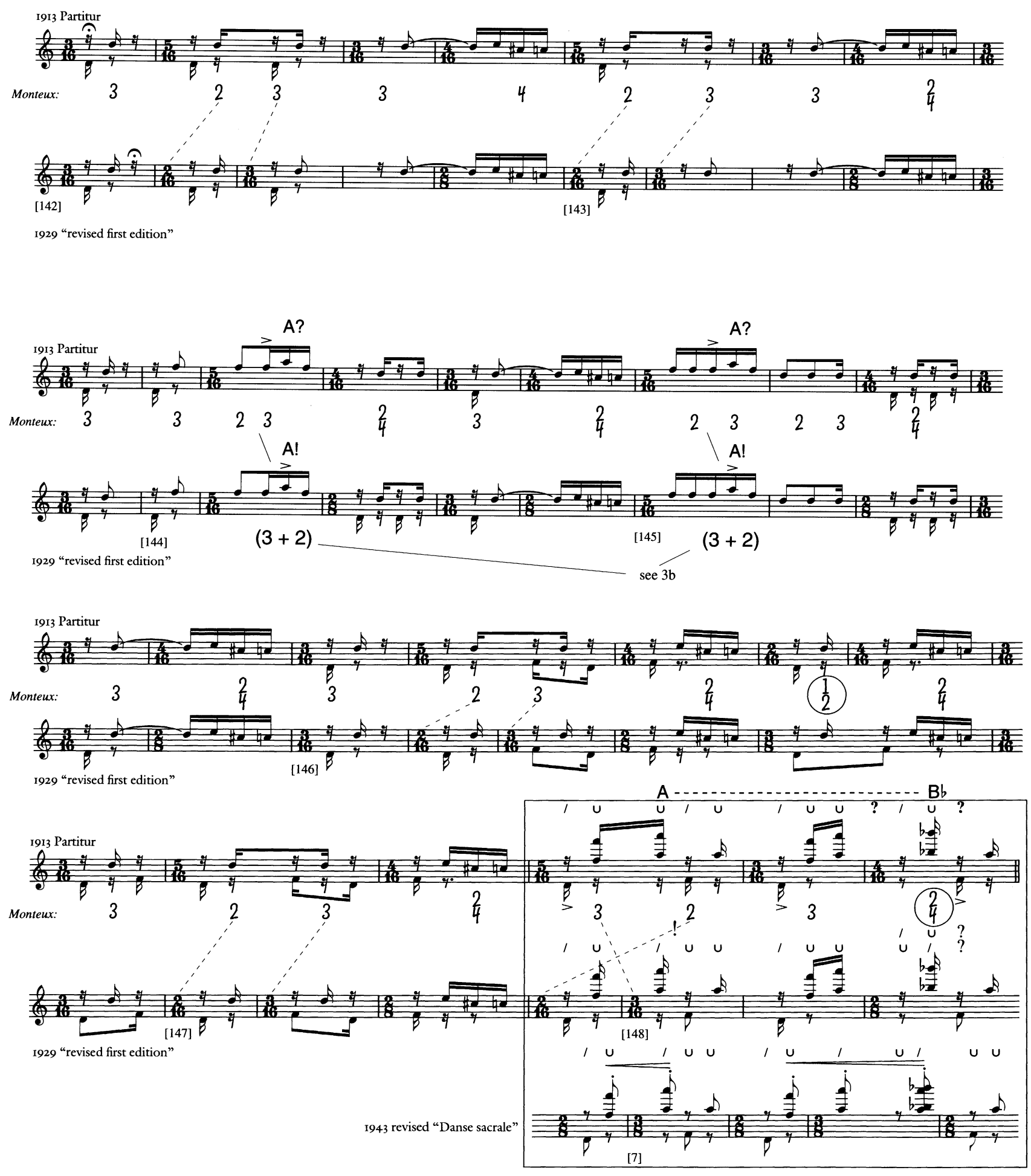

${ }^{100}$ Robert Fink, "Rigoroso $(\delta=126)$ ": "The Rite of Spring" and the Forging of a Modernist Performing Style, Journal of the American Musicological Society, Vol. 52, No. 2 (Summer, 1999), 320-321. 
Another phrase that requires special attention is the four-bar phrase at one measure before no. 148 (shown in the box from Example 14). Monteux reasonably made the division of $3+2$ in the 5/16 measure from the 1913 Partitur; initially Stravinsky intended the division of $3+2$ (in the 1913 autograph full score) by grouping the second and the third sixteenth notes together. In 1929 edition, however, Stravinsky separated the 5/16 measure into 2/16 +3/16 while retaining the following two measures without change.

Finally, in the 1943 revision of the Danse sacrale, he found the most logical solution: he made the rhythmic sequence by repeating the $(2 / 8+3 / 8)$ rhythmic motive ("rhythmic cell" as Boulez would call it) with the remaining $2 / 8$ at the end. With this new grouping, Stravinsky achieved a sense of rhythmic symmetry as well as a hierarchical relationship within the rhythmic cell; the 2/8 measure functions as an anacrusis, and a strong accent is placed on the downbeat of the following $3 / 8$ measure.

Determining the "correct divisions" in asymmetrical meters from Le Sacre is one of the prerequisites for conducting this rhythmically challenging score; most notably in the "Glorification of the chosen one" (no. 104-121), and in some of the Danse sacrale. However, in contrast to the "Glorification of the chosen one" where most of the measures are compounded (thus requiring correct divisions), the Danse sacrale also requires the "correct groupings" of the measures in order to identify the rhythmic rhetoric: that is, the rhythmic cells and rhythmic phrases. In this context, Boulez's rhythmic cell analysis is extremely beneficial to find the "correct bar-groupings." Furthermore, studying the original barring from the sketchbook and the 1913 autograph full score of Le Sacre, offers us invaluable clues when determining the correct groupings. By identifying the correct groupings, the hierarchical relationship within a rhythmic cell can be determined, which will eventually provide the key to conduct the rhythmic phrases more coherently rather than simply beating the time in each measure.

The next point to consider when conducting the Danse sacrale is tempo. Although Le Sacre was written as ballet music, Stravinsky considered it as "more symphonic, more of a concert piece, than Petroushka."101 Stravinsky recalled, "I have seen only one stage version (for ballet) of Le Sacre since 1913, and that was Diaghilev's 1921 revival."102 The 1913 première of Le Sacre is considered to be one of the biggest scandals in music history; we know not only of

\footnotetext{
101 Stravinsky and Craft, Expositions and Developments (New York: Doubleday, 1962), 144. 102 Ibid.
} 
the riot by the hostile audience members but also of the fact that the performance was poorly executed in terms of the coordination between music and dance. Monteux's modifications for tempo indications in many dances including the Danse sacrale from the 1913 autograph full score can be found in his annotations. He often had to ignore Stravinsky's original tempo indications in order to make the music “danceable” following Nijinsky's choreography. In other words, choreographic demands forced him to abandon the composer's original tempo markings.

Tempo indications for the Danse sacrale did not appear in the sketchbook, the short score of manuscript, or the autograph full score; they first appeared in the four-hand score (RMV 196). In the four-hand piano score, Stravinsky gives three important directions for tempo: (1) Metronome marking indicates eighth note equals 126. (2) The tempo in B section should stay the same as A section. (3) At the first Coda (no. 174), the tempo should be slower (from 126 to 116). Stravinsky further provides the tempo expression "Sostenuto e maestoso" at no. 174. He also changed the note value from eighth note to quarter note at no. 174 (see Example 15).

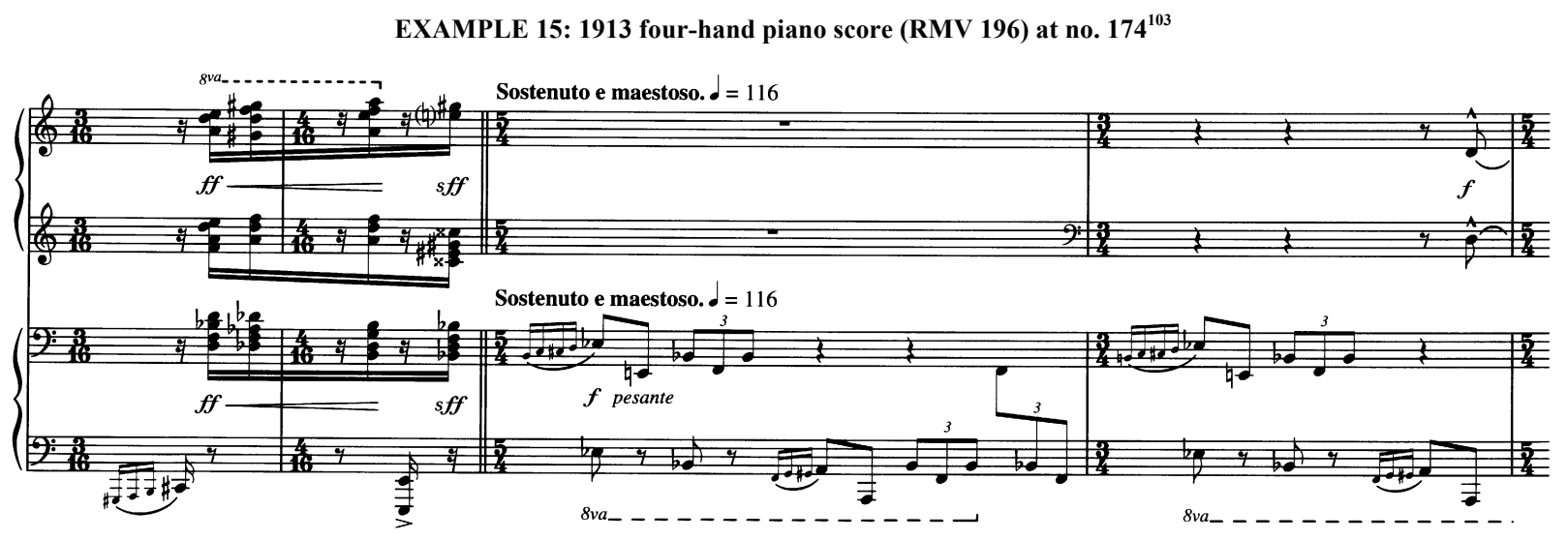

Since the first printed edition of the full score (RMV 197), Stravinsky had removed the tempo expression and changed the metronome marking at no. 174 from 116 to 126 . Thus, he established the tempo relationship between the A section, B section and Coda I: the tempo stays virtually the same. Moreover, in the 1943 revision, Stravinsky managed to keep the basic note value as an eighth note in Coda I, which is the same as the previous sections (before no. 174) where the basic note value was doubled from sixteenth note to eighth note.

Table 4 (below) shows the tempo indications for the Danse sacrale in different editions. In the 1943 version, Stravinsky gives the tempo expression "Rigoroso" at the beginning of the

\footnotetext{
103 Robert Fink, "Rigoroso $(\delta=126)$ ": "The Rite of Spring" and the Forging of a Modernist Performing Style, Journal of the American Musicological Society, Vol. 52, No. 2 (Summer, 1999), 336.
} 
piece. Other than the tempo expression and the metronome marking at the beginning, the 1943 version needs no further tempo indications since Stravinsky resolved all tempo issues.

Table 4: Concordance of Tempo Indications in the Danse sacrale ${ }^{104}$

\begin{tabular}{|c|c|c|c|c|c|c|c|}
\hline Location & Sketchbook [A] & Partitur [C] & $\begin{array}{l}\text { IS } 1913 \text { piano } \\
\text { score [D] }\end{array}$ & $\begin{array}{l}\text { IS } 1922 \text { printed } \\
\text { scores [E-F] }\end{array}$ & $\begin{array}{l}1929 \text { "revised first } \\
\text { edition" [F2] }\end{array}$ & 1943 revision $[\mathrm{G}]$ & $\begin{array}{l}1967 \text { "final } \\
\text { edition" }[\mathrm{I}]\end{array}$ \\
\hline $\mathrm{Rl} 42$ & $\begin{array}{l}\text { fermata before lst } \\
\text { chord, not after } \\
\text { [ never after in whole } \\
\text { sketchbook]; same in } \\
\text { Particell (this is the } \\
\text { end of Particell) }\end{array}$ & $\begin{array}{l}\text { fermata before 1st } \\
\text { chord, not after; also } \\
\text { seems to be fermata } \\
\text { on b cl. note! }\end{array}$ & $\begin{array}{l}\text { fermata before lst chord, } \\
\text { not after; also seems to be } \\
\text { fermata on b cl. note! }\end{array}$ & $\begin{array}{l}\text { fermata before lst chord, } \\
\text { not after }\end{array}$ & fermata after lst chord & fermata after lst chord & fermata after lst chord \\
\hline $\mathrm{R} 142$ & no tempo marking & no tempo marking & $\lambda=126$ & $\lambda=126$ & $\lambda=126$ & $\begin{array}{l}\text { Rigoroso }(\delta=126) ; \\
\text { this is a misprint } \\
\text { for } \downarrow=126\end{array}$ & $\delta=126$ \\
\hline Rl49 & $\begin{array}{l}\text { pocchisimo meno mosso } \\
\text { [p. 84] Luftpause [p. 85] }\end{array}$ & nothing & $\rho=\delta$ & $A=A$ & $A=A$ & nothing & $A=A$ \\
\hline Rl61 & nothing & $\begin{array}{l}\text { conductor writes in } \\
\text { accel. }\end{array}$ & nothing & nothing & nothing & nothing & nothing \\
\hline Rl67 - I & $\begin{array}{l}\text { fermata on last sixteenth; } \\
\text { no accel. or cresc. }\end{array}$ & nothing & $\begin{array}{l}\text { crescendo and fermata; } \\
\text { no accel. }\end{array}$ & $\begin{array}{l}\text { accelerando e cresc.; } \\
\text { fermata on last sixteenth; } \\
\text { Stravinsky's markings } \\
\text { confirm fermata; " } v w \text { " } \\
\text { over accel. bar? }\end{array}$ & $\begin{array}{l}\text { accel. e cresc.; fermata } \\
\text { on last sixteenth }\end{array}$ & $\begin{array}{l}\text { no accel., no cresc., } \\
\text { and no fermata [!] }\end{array}$ & $\begin{array}{l}\text { accel. e cresc.; fermata } \\
\text { on last sixteenth }\end{array}$ \\
\hline $\mathrm{Rl} 67$ & not actually written out & nothing & nothing & nothing & nothing & nothing & $A=A$ \\
\hline $\mathrm{Rl} 74$ & $\begin{array}{l}\text { nothing (and the } \\
\text { beginning is sketched } \\
\text { out several times) }\end{array}$ & $\begin{array}{l}\text { nothing (no } \\
\text { equivalencies written } \\
\text { in, but no conductor's } \\
\text { marks either) }\end{array}$ & $\begin{array}{l}\text { Sostenuto e maestoso. } \\
d=116 ; \text { IS carefully } \\
\text { corrects this (twice) to } \\
d=126 \text { in his copy, but } \\
\text { does not cross out } \\
\text { the performance direction }\end{array}$ & $\begin{array}{l}=126 \\
\text { IS pocket score (RMV } \\
197 b ; \text { inscribed "Igor } \\
\text { Stravinsky/Paris, 1922) } \\
\text { has red markings enforcing } \\
\text { the tempo equivalencies } \\
(\AA=\delta=d=126 \text {, etc.) } \\
\text { written into score, } \\
\text { here and everywhere } \\
\text { IS's full score (RMV 197) } \\
\text { has been reworked to form } \\
\text { the basis of the } 1929 \\
\text { "standard" version (126 } \\
\text { enforced at all junctures) } \\
\end{array}$ & $f=d 26$ & nothing & $d=d=126$ \\
\hline $\mathrm{Rl} 80$ & $\begin{array}{l}\text { nothing (spot is never } \\
\text { sketched as such); it } \\
\text { appears that going back } \\
\text { to the A section between } \\
\text { the two explosions was } \\
\text { not part of original } \\
\text { conception [p. } 97 \\
\text { bottom] }\end{array}$ & nothing & nothing; fermata & $\begin{array}{l}D=126 \text {; fermata } \\
\text { IS confirms fermata }\end{array}$ & $d=\delta ; \downarrow=126 ;$ fermata & fermata & $d=d=126$; fermata \\
\hline R181 & see above & \begin{tabular}{|l} 
nothing; conductor \\
confirms fermata over \\
bar line of R181
\end{tabular} & nothing (no fermata) & $\begin{array}{l}\text { fermata; } d=126 \\
\text { IS confirms fermata }\end{array}$ & $\begin{array}{l}\text { fermata on bar line; } \\
\lambda=d ; d=126\end{array}$ & fermata on bar line & $\rho=d=126$ \\
\hline Ri86 & nothing & \begin{tabular}{|l|} 
conductor writes in \\
"Vivo"; dynamic is $p$ \\
[horns, bassoons]
\end{tabular} & nothing; dynamic is $p p$ & $\begin{array}{l}\delta=126 \text {; dynamic is } p \\
\text { [horns, bassoons] }\end{array}$ & $\begin{array}{l}d=\downarrow=126 ; \text { dynamic } \\
\text { is } f \text { to } f f f \text { sempre [ben] } \\
\text { marcato or } f \text { sempre } \\
\text { [bassoons, all low brass] }\end{array}$ & $\begin{array}{l}\text { nothing; dynamic is } \\
\text { sf marcato, but } \\
\text { orchestration is cut } \\
\text { down to bassoons and } \\
\text { pizzicato lower strings }\end{array}$ & $\begin{array}{l}d=\delta=126 \text {; dynamic } \\
\text { is } f \text { to } f f f \text { sempre [ben] } \\
\text { marcato or sf sempre }\end{array}$ \\
\hline R201 & $\begin{array}{l}\text { trill is already "lunga } \\
\text { ad lib" on p. } 87 \text { and } \\
\text { even more so on p. } 89\end{array}$ & $\begin{array}{l}\text { lunga ad lib in vln } 1 \\
\text { part at R201 + } 1 \text { in } \\
\text { final chord, bass player } \\
\text { are told [in ink] to } \\
\text { "play the low d on the } \\
\text { C-string" }\end{array}$ & $\begin{array}{l}\text { accel. then a tempo; } \\
\text { trill is marked lunga } \\
\text { rs ad lib. }\end{array}$ & $\begin{array}{l}\text { no accel.; trill (now a } \\
\text { tremolo) is marked with } \\
\text { fermata and lunga ad lib.: } \\
\text { ww are colla parte [no IS } \\
\text { markings] }\end{array}$ & $\begin{array}{l}\text { lunga ad lib is removed; } \\
\text { but ww colla parte stays }\end{array}$ & $\begin{array}{l}\text { tremolo removed, } \\
\text { replaced with a single } \\
\text { solo violin playing f\#; } \\
\text { bar has a fermata }\end{array}$ & $\begin{array}{l}\text { lunga ad lib is } \\
\text { removed, but ww colla } \\
\text { parte stays }\end{array}$ \\
\hline
\end{tabular}

Note: In column headings the bracketed letters refer to primary sources listed in Works Cited; the Particell is lacking the "Danse sacrale"; IS = Stravinsky's annotated copy, used for rehearsal/performance.

104 Robert Fink, "Rigoroso $(\delta=126)$ ": "The Rite of Spring" and the Forging of a Modernist Performing Style, Journal of the American Musicological Society, Vol. 52, No. 2 (Summer, 1999), 353-354. 
The first generation of Le Sacre conductors (Monteux, Ansermet, Koussevitzky, Goossens, Stokowski, and Stravinsky himself) took more liberties and often ignored the composer's original tempo indications when they conducted the piece in concert performances or in recordings. One example can be found in Nicholas Slonimsky's vivid memory of Koussevitzky's struggles when he conducted the piece:

\begin{abstract}
When precise metrical changes occurred, as from 3/16 to $2 / 8$, he kept slowing down the sixteenth-notes and accelerating the eighth-notes so that the distinct binary rations dissolved into formless neutral triplets...

Koussevitzky also had trouble in passages of $5 / 8$ in a relatively moderate time, particularly when $5 / 8$ was changed to $6 / 8$, or to $9 / 8$ as happened in Stravinsky's score. ${ }^{105}$
\end{abstract}

Koussevitzky's case was mostly due to his inadequate conducting technique. However, other conductors' tempo modifications (or distortions) were perhaps driven by their interpretive decisions. Although there are no recordings of Le Sacre conducted by Koussevitzky available, historical early recordings of Le Sacre conducted by others who were mentioned above exist. The earliest recordings of Le Sacre were made by both Stravinsky and Monteux in 1929. Stravinsky recorded Le Sacre three times: in 1929, 1940, and 1960.

Table 5 (below) shows some recorded tempos in the Danse sacrale from several different recordings. Several observations deserve to be mentioned. First, Stravinsky takes different tempos in each of his recordings. He not only chose slightly different tempos in each recording but took different tempos in different sections of the Danse sacrale in spite of his own indications that all sections in the Danse sacrale maintain the same tempo except for the two measures of accelerando before no. 167. In all three recordings, Stravinsky tends to take a faster tempo for the B section than the A section. Of his three recordings, the 1960 recording seems to keep the tempo consistently throughout using a tempo closest to his tempo indication in the score: eighth equals to 126. Second, all conductors (except for Stravinsky's 1960 recording) slow down at Coda I (no. 174). One possible explanation why only Stravinsky's 1960 recording keeps the same tempo might be the fact that it is the only recording that used the 1943 revised version of the Danse sacrale. As explained above, the 1943 version unified the basic note value throughout the piece by doubling the basic note value from sixteenth to eighth. Thus, the basic note value at Coda I (no. 174) stays the same as the previous section.

105 Nicholas Slonimsky, Perfect Pitch (Oxford: Oxford University Press, 1988), 74-75. 
Table 5: Some Recorded Tempos in the Danse sacrale (a survey done by Robert Fink) ${ }^{106}$

\begin{tabular}{|c|c|c|c|c|c|c|c|c|c|c|}
\hline Performance & $\begin{array}{c}\mathrm{A} \\
\mathrm{R} \mathrm{l} 42\end{array}$ & $\begin{array}{c}\text { B } \\
\text { Rl49 }\end{array}$ & $\begin{array}{l}\text { rit.? } \\
\text { Rl61 }\end{array}$ & $\begin{array}{l}\text { accel.? } \\
\text { bef Rl67 }\end{array}$ & $\begin{array}{c}\mathrm{A}^{\prime} \\
\mathrm{R} 167\end{array}$ & $\begin{array}{c}\mathrm{Cl} \\
\mathrm{Rl74}\end{array}$ & $\begin{array}{c}\text { A } \\
\text { R180 }\end{array}$ & $\begin{array}{c}\mathrm{C} 2 \\
\mathrm{R} 181\end{array}$ & $\begin{array}{c}\mathrm{A}^{\prime \prime} \\
\mathrm{R} 186\end{array}$ & $\begin{array}{l}\text { end } \\
\text { R199-end }\end{array}$ \\
\hline $\begin{array}{l}\text { Bernstein } 1958 \\
{[4: 27]}\end{array}$ & $138-42$ & $130-32$ & no rit. & no accel. & $138-44$ & $\begin{array}{l}122-25 \text {; accel to } \\
\text { ca. } 1410 \text { at R180! }\end{array}$ & 138 & $\begin{array}{c}112-16 ;^{\mathrm{a}} \\
\text { very broad; } \\
\text { no accel. to end }\end{array}$ & $\begin{array}{l}\text { wants sudden } \\
138 ;^{\text {b gets }} \\
127-30 \\
\text { starts accel. }\end{array}$ & $140+$ \\
\hline $\begin{array}{l}\text { Stokowski } 1930 \\
{[4: 53]}\end{array}$ & $126-28$ & $115-18$ & slight rit. & $\begin{array}{l}\text { accel. only } \\
\text { to } 126-32\end{array}$ & $\begin{array}{l}\text { 116-18; } \\
\text { attempted } \\
\text { accel. }(128) \\
\text { collapses }\end{array}$ & $\begin{array}{l}105-8 \text {; slight } \\
\text { push at Rl78; } \\
\text { sudden accel. } \\
\text { to ca. } 126 \text { at end }\end{array}$ & 128 & $\begin{array}{l}\text { 98-100! } \\
\text { very broad; } \\
\text { Ri } 84-86 \\
\text { speeds up very } \\
\text { slightly 106-8 }\end{array}$ & $\begin{array}{l}\text { wants 135-37 } \\
\text { (gets it in } \\
\text { low strings) }\end{array}$ & $\begin{array}{l}\text { no accel.; } \\
\text { ca. } 132\end{array}$ \\
\hline $\begin{array}{l}\text { Goossens } 1960 \\
\text { [4:39] }\end{array}$ & $126-32$ & $124-26$ & slight rit. & no & $133-35$ & $116-18$ & 132 & $\begin{array}{l}\text { starts at } 96 ; \\
\text { stabilizes at } \\
114-16\end{array}$ & $\begin{array}{c}\text { wants } 148-50 \text { ! } \\
\text { gets } 136-40\end{array}$ & $\begin{array}{l}\text { bass drum } \\
\text { drives accel. } \\
\text { to } 140-44\end{array}$ \\
\hline $\begin{array}{l}\text { Ansermet } 1957 \\
{[4: 42]}\end{array}$ & 126 & $134-36$ & rit. & no & 126 & $\begin{array}{l}102-6 ; 112 \\
\text { at R178; pushes } \\
\text { to } 116 \text { at last bar }\end{array}$ & 126 & $\begin{array}{c}116-20 \\
\text { slight accel. } \\
\text { to } 122-24\end{array}$ & $\begin{array}{c}\text { wants } 135 \\
\text { settles into } 126\end{array}$ & $\begin{array}{l}\text { bass drum } \\
\text { drives slight } \\
\text { accel. (132?) }\end{array}$ \\
\hline $\begin{array}{l}\text { Monteux } 1929 \\
{[4: 15]}\end{array}$ & $148-53$ & $133-45$ & no rit. & accel. to 157 ! & $146-48$ & $\begin{array}{c}124-26 \\
\text { slow accel. } \\
\text { to } 133^{c}\end{array}$ & $\begin{array}{l}\text { tries for } \\
145-48\end{array}$ & $\begin{array}{l}\text { starts at } 116-20, \\
\text { then accel. to } \\
133 \text { at R184 and } \\
\text { ca. } 138 \text { at R186 }\end{array}$ & $\begin{array}{l}\text { wants } 152[!] \\
\text { and almost gets } \\
\text { it; falls back } \\
\text { to } 148\end{array}$ & $\begin{array}{c}\text { accel. to } \\
155+\end{array}$ \\
\hline $\begin{array}{l}\text { Stravinsky } 1929 \\
{[4: 58]}\end{array}$ & $108-12$ & $\begin{array}{c}119-20 \text { accel. } \\
\text { to ca. } 130\end{array}$ & no rit. & $\begin{array}{l}\text { accel. to } \\
\text { ca. } 140\end{array}$ & $110-13$ & $\begin{array}{c}\text { ca. } 99 ; \\
\text { accel. after } \\
\text { Rl78 to ca. } 116\end{array}$ & 116 & $\begin{array}{c}\text { 108-13; } \\
\text { solid } 113 \\
\text { after R184 }\end{array}$ & $\begin{array}{c}\text { wants } \\
124-26 ?^{e} \\
\text { falls back to } \\
\text { to ca. } 113\end{array}$ & ca. $120-24$ \\
\hline $\begin{array}{l}\text { Stravinsky } 1940 \\
{[4: 24]}\end{array}$ & $\begin{array}{c}\text { 113; tries } \\
\text { to push } \\
\text { (ca. 118-20?) }\end{array}$ & $\begin{array}{c}143-45[!] ; \\
\text { pushes to } \\
150-55 \text { at } f f\end{array}$ & no & $\begin{array}{l}\text { accel. to } \\
\text { ca. } 160 !\end{array}$ & $\begin{array}{c}130-32, \mathrm{f} \\
\text { but loses } \\
\text { tempo to } \\
122-26\end{array}$ & $\begin{array}{c}127-33 ; \\
\text { steady at } \\
130-32 \\
\text { after R178 }\end{array}$ & $126-27$ & $127-31$ & $\begin{array}{l}\text { tries to stay } \\
\text { at } 127-30 ; \\
\text { messy but } \\
\text { basically there }\end{array}$ & $\begin{array}{c}\text { pushes to } \\
138 \text { ? }\end{array}$ \\
\hline $\begin{array}{l}\text { Stravinsky } 1960 \\
{[4: 31]}\end{array}$ & $120-22$ & $135-38$ & no & accel. to 145 & $122-26$ & $\begin{array}{c}124-26 ; \\
\text { pushes slightly } \\
\text { after R178 }\end{array}$ & $122-26$ & $130-32$ & $\begin{array}{c}\text { remains a } \\
\text { tempo at } 130-32 \text {; } \\
\text { perfect ensemble }\end{array}$ & $\begin{array}{l}\text { 122-26; } \\
\text { no accel. }\end{array}$ \\
\hline $\begin{array}{l}\text { Pianola } 1921^{\mathrm{h}} \\
{[4: 13]}\end{array}$ & $140-44$ & $134-39$ & no & accel. to 144 & $135-40$ & $124-26$ & 135 & $\begin{array}{l}\text { starts at } 108-10, \\
\text { then steadies at } \\
\text { ca. } 118-20\end{array}$ & $\begin{array}{l}\text { sudden speed } \\
\text { up to } 150-54\end{array}$ & $\begin{array}{l}\text { no accel. } \\
\text { except right } \\
\text { at R201 }\end{array}$ \\
\hline
\end{tabular}

aIf one were to calculate tempo from first two quarters, it would be $\rfloor=96$ ! Agogic slowdown is noticeable

bAuthor's inference of desired tempo from moments of collapsed ensemble; in this case, calculated from the tuba/bass/contrabassoon part in Rl86.

'Accel. begins with the reiterated offbeat D's at R178; same in 1951 recording.

"Very hard to hear; tempo is inferred from bass/tuba part.

${ }^{C}$ Extremely hard to hear (messiest section of recording); tempo inferred from bass figure at R186 and following string sixteenths.

fClever! By taking the B section so fast, Stravinsky is able to get the orchestra to take A at a decent speed the second time around.

gProblem: bass drum (where one usually gets tempo) is out of time here.

${ }^{\mathrm{h}}$ As realized by Rex Lawson on Innovative Music Masters CD MCD25, 1989.

Other than Stravinsky's own recordings, recordings by Monteux and Ansermet show some interesting contrast in choosing the tempos in the Danse sacrale. Ansermet's overall tempos are chosen more faithfully to Stravinsky's tempo indications; however, he increased the tempo in the B section. In contrast, Monteux takes the fastest rendition of the Danse sacrale in his 1929 recording.

The long and complicated journey that Stravinsky took in honing Le Sacre du printemps (particularly for the Danse sacrale) seemed never-ending but fortunately, we have enough evidence to help us to understand what he intended to do both musically and intellectually in this revolutionary piece. Thorough studies and analyses of the score, performing materials and the recorded performance practices is the key to solve the riddle that Le Sacre presents to all conductors and performers.

\footnotetext{
106 Robert Fink, "Rigoroso $(\delta=126)$ ": "The Rite of Spring" and the Forging of a Modernist Performing Style, Journal of the American Musicological Society, Vol. 52, No. 2 (Summer, 1999), 356.
} 


\section{Chapter 6}

\section{Summary and Conclusions}

No other work by Stravinsky presents a more complicated history of revisions than Le Sacre du printemps. From the 1912 sketchbook (the facsimile autographs were published in 1969 by Boosey and Hawkes) to the final 1967 version, the evolution of the score spanned more than a half-century. He revised the score several times as he encountered errors and other musical issues from his own experience of studying and conducting the piece as well as from numerous observations and suggestions made by the first generation of Le Sacre conductors, most notably Pierre Monteux and Ernest Ansermet. Both Monteux and Ansermet played important roles in the revision process. Especially, Monteux's score markings for bar-divisions from the autograph full score contributed greatly to Stravinsky's re-barring of the 1929-revised version. Ansermet was even more actively involved in the revision process; his Erratumblatt and "the directions for the conductor" from the letter in 1922 helped the composer to revise, especially, the Danse sacrale with the changes of metrical plans (from an asymmetrical meter of 5/16 and a compounded meter of 6/16 to the smaller divisions of twos and threes) as well as the orchestration (the removal of pizzicati). The correspondences between Ansermet and Stravinsky offer some invaluable insight for the evolution of the Danse sacrale.

In 1943, Stravinsky completely rewrote the Danse sacrale. With the new version of the Danse sacrale, he intended to resolve several issues that the final dance of Le Sacre had been presenting up to that point. First, Stravinsky changed the basic note value from sixteenth to eighth, and removed all beams from the note heads. It not only helped some conductors to read the seemingly complex score with more ease, but also resolved the problematic implication of slowing down the tempo (because of the double value of the note) in Coda I (no. 174) that the previous version presented. Second, he reorganized the metrical plan, some of which he changed back to the 1913 original autograph version. Third, he re-orchestrated the score almost completely to achieve better balance and sonority. Despite his wish for the 1943 revision of the Danse sacrale to supersede the previous versions, the new version for the Danse sacrale failed to be accepted by most performers and scholars. There are three major flaws in the 1943 version. First, the new orchestration weakened the thick, powerful sound force from the original texture. 
Second, the change of the metrical plan at the beginning (from $2+3$ to $3+2$ ) hinders the hierarchical relationship between the two measures; the duple measure functions as an anacrusis followed by the strong downbeat at the triple measure. Third, the removal of beams (especially in the B section) hinders us from seeing the larger rhythmic structures. Therefore, the author would not use the 1943 version for his own performance.

Nicholas Slonimsky's re-barring of the Danse sacrale (1921) was intended to aid Serge Koussevitzky's deficient conducting technique for handling the constant metrical changes. It provided Koussevitzky with an easy alternative solution to conduct the rhythmically challenging score; it also benefited Koussevitzky’s protégé Leonard Bernstein. Although Slonimsky’s rebarring makes it easier to conduct, it presents fundamental problems as well as practical problems for players. First, it ignores the intrinsic rhythmic rhetoric; the inherent nature of rhythmic phrases is completely disregarded. Second, by shifting the syncopations to downbeats, its rhythmic essence has been lost. Therefore, the author would not use Slonimsky's re-barring for his own performance.

To understand the rhythmic structure of the Danse sacrale, a rhythmic analysis is helpful. Pierre Boulez's rhythmic cell analysis helps us to understand the coherent rhythmic structure of the piece from small units to larger divisions. He shows how the cells are organized and transformed. The most significant benefit of Boulez's rhythmic cell analysis is to understand the hidden symmetrical structure in the Danse sacrale, which appears to have irregular rhythms. The study of rhythmic cells and rhythmic phrases also helps the conductor to determine coherent conducting beat patterns.

Conducting Le Sacre requires a tremendous amount of study and investigation of the performance materials, including the sketchbook, the autograph full score, and the existing recordings by Stravinsky. To identify the correct metrical divisions and groupings is essential. The tempo issues in the Danse sacrale seem to have been complicated by various conductors' interpretive decisions. However, it becomes clear after thorough investigation of tempo indications from various performing materials that Stravinsky intended to keep the same tempo (126 beats per minute) consistently throughout the Danse sacrale. As Stravinsky made constant revisions to achieve more clarity for his intentions in the score, it is conductors' duty to solve the puzzle in order to unfold the composer's original intentions, the inner spirit of the piece, and to recreate the original inspiration that Stravinsky first experienced. 
Bibliography

Boulez, Pierre. Notes of an Apprenticeship. New York: Alfred A. Knopf, 1968.

Chua, Daniel K. L. "Rioting with Stravinsky: A Particular Analysis of the Rite of Spring." Music Analysis 26, no. 1-2 (March-July 2007): 59-109.

Craft, Robert Lawson. "Le Sacre du printemps: The Revisions." Tempo: A Quarterly Review of Modern Music, no. 122 (September 1977): 2-8.

1982. , ed. Stravinsky: Selected Correspondence, vol. 1, 2. New York: Alfred A. Knopf,

Craft, Robert Lawson and Vera Stravinsky. Stravinsky in Pictures and Documents. NewYork: Simon \& Schuster, 1978.

Cross, Jonathan. The Cambridge Companion to Stravinsky. Cambridge: Cambridge University Press, 2003.

Cyr, Louis. "Writing The Rite Right," Confronting Stravinsky. Berkeley: University of California Press, 1986.

Danuser, Herman, ed. Avatar of Modernity: The Rite of Spring Reconsidered. London: Boosey \& Hawkes, 2013.

Eigeldinger, Jean-Jacques. "An Unpublished Letter from Ansermet to Stravinsky about Le Sacre du printemps." Revue Musicale De Suisse Romande 35, no. 5 (December 1980): 210.

Fink, Robert. "Rigoroso ( $\delta=126)$ ": "The Rite of Spring" and the Forging of a Modernist Performing Style. Journal of the American Musicological Society, Vol. 52, No. 2 (Summer 1999)

Hill, Peter. Stravinsky: The Rite of Spring. New York: Cambridge University Press, 2000.

Manulkina, Olga. "Leonard Bernstein's 1959 Triumph in the Soviet Union," The Rite of Spring at 100. Bloomington: Indiana University Press, 2017.

McBride, Melissa. "Stravinsky's Last Danse Sacrificed? The 1943 Revision of the Sacrificial Dance from the Rite of Spring." D.M.A., Stanford University, 1993.

Messiaen, Olivier. The Technique of My Musical Language. Paris: Alphonse Leduc, 1956.

Meyer, Felix, ed. Igor Stravinsky, Le Sacre du printemps: Manuscript of the Version for Piano Four Hands: Facsimile. London: Boosey \& Hawkes, 2013.

Mosch, Ulrich. Igor Stravinsky: Le Sacre du printemps (1910-13). Mainz: Schott Musik International, 1998. 
, ed. Igor Stravinsky, Le Sacre du printemps: Facsimile of the Autograph Full Score.

London: Boosey \& Hawkes, 2013.

New York Philharmonic: Leon Levy Digital Archives. "The Rite of Spring.” (ID: 2341)

Accessed July 6, 2017.

http://archives.nyphil.org/index.php/artifact/75ac165a-d69a-462b-80c8-

b7bc21ca15c2/fullview

Pasler, Jann, ed. Confronting Stravinsky: Man, Musician, and Modernist. Berkeley: University of California Press, 1986.

Peyser, Joan. To Boulez and Beyond: Music in Europe since the Rite of Spring. New York: Billboard Books, 1999.

Siddons, James. "Rhythmic Structures in Le Sacre du printemps (Danse sacrale)." Musical Analysis 1, no. 1 (Winter 1972): 6-11.

Stravinsky, Igor. Le Sacre du printemps. Sketches 1911-1913. Facsimile Reproductions from the Autographs. London: Boosey \& Hawkes, 1969.

Stravinsky, Igor and Ernest Ansermet. Correspondence Ansermet-Strawinsky (1914-1967).

Genève: Georg, 1990.

Stravinsky, Igor and Robert Craft. Expositions and Developments. New York: Doubleday, 1962.

Sternberg, Jonathan. "Scores and Parts: Stravinsky's The Rite of Spring." Journal of the Conductor's Guild, vol.5/2 (Winter 1989)

Tappolet, Claude, ed. Correspondence: Ernest Ansermet-Igor Stravinsky, vol.2. Geneva: George Éditeur, 1991.

Taruskin, Richard. The Rite Revisited: The Idea and the Sources of its Scenario. New York: W.W. Norton, 1984.

Press, 1996. . Stravinsky and the Russian Traditions, Vol. 1. Berkeley: University of California

Toorn, Pieter C. van den. Stravinsky and the Rite of Spring: The Beginnings of a Musical Language. Oxford: Oxford University Press, 1987.

White, Kathy Maria. "The Rite of Spring: A Rhythmic Perspective." D.M.A., Washington University, St. Louis, 1987.

Woodruff, Ghofur Eliot. "Metrical Phase Shifts in Stravinsky's the Rite of Spring." Music Theory Online 12, no. 1 (February 2006). 